\title{
Glia and Neural Stem and Progenitor Cells of the Healthy and Ischemic Brain: The Workplace for the Wnt Signaling Pathway
}

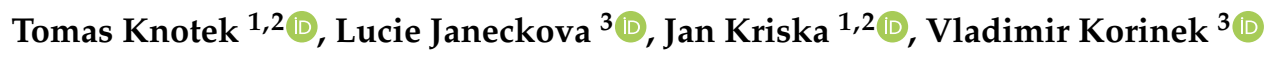 \\ and Miroslava Anderova 1,2,* \\ 1 Institute of Experimental Medicine, Czech Academy of Sciences, 1083 Videnska, 14220 Prague, \\ Czech Republic; tomas.knotek@iem.cas.cz (T.K.); jan.kriska@iem.cas.cz (J.K.) \\ 2 Second Faculty of Medicine, Charles University, 84 V Uvalu, 15006 Prague, Czech Republic \\ 3 Institute of Molecular Genetics, Czech Academy of Sciences, 1083 Videnska, 14220 Prague, Czech Republic; \\ lucie.janeckova@img.cas.cz (L.J.); vladimir.korinek@img.cas.cz (V.K.) \\ * Correspondence: miroslava.anderova@iem.cas.cz; Tel.: +420-241-062-050
}

Received: 29 June 2020; Accepted: 15 July 2020; Published: 16 July 2020

check for updates

\begin{abstract}
Wnt signaling plays an important role in the self-renewal, fate-commitment and survival of the neural stem/progenitor cells (NS/PCs) of the adult central nervous system (CNS). Ischemic stroke impairs the proper functioning of the CNS and, therefore, active Wnt signaling may prevent, ameliorate, or even reverse the negative effects of ischemic brain injury. In this review, we provide the current knowledge of Wnt signaling in the adult CNS, its status in diverse cell types, and the Wnt pathway's impact on the properties of NS/PCs and glial cells in the context of ischemic injury. Finally, we summarize promising strategies that might be considered for stroke therapy, and we outline possible future directions of the field.
\end{abstract}

Keywords: Wnt signaling; central nervous system; neural stem/progenitor cell; glia; subventricular zone; subgranular zone; ischemia; stroke; adult neurogenesis

\section{Introduction}

In the central nervous system (CNS), Wnt signaling plays a pivotal role in embryogenesis, but it is also decisive postnatally, especially in regulating the proliferation, differentiation and migration of adult neural stem/progenitor cells (NS/PCs). In recent years, new links between Wnt signaling and a multitude of neuronal impairments affecting the CNS have emerged. Among others, schizophrenia [1], Alzheimer's [2] and Parkinson's diseases [3] are mental and neurodegenerative disorders that subvert the adult and aged mammalian brain. Nevertheless, this review mainly focuses on cerebral ischemia-acute brain injury associated with neurodegeneration. This medical condition negatively affects a broad spectrum of cells in the CNS, changing their behavior, functions and gene expression (reviewed in Reference [4]). However, there is a wide range of factors that might potentially help overcome the negative effects of ischemia. One of the cellular signaling pathways influenced by, and yet affecting the output of, ischemia is Wnt signaling. It has an indisputable function in the neuroprotection and regeneration of the CNS [5,6]. Wnt signaling affects the properties of NS/PCs and neuron-glial antigen 2 (NG2)-expressing cells, a glial type of cells that act as oligodendrocyte precursor cells (OPCs) in the healthy brain, and together with NS/PCs, they have a multipotent differentiation potential following brain injury [7-9]. This review summarizes recent findings on the role of the Wnt signaling pathway in the proliferation and differentiation of NS/PCs, and in the properties of other cell types in the CNS under ischemic conditions. Furthermore, we provide evidence that Wnt signaling should be considered in the treatment of ischemic brain injury. 


\section{Wnt Signaling}

Wnt proteins act as important morphogens during embryogenesis, and their impact was also proven in postnatal ontogenetic stages, where they influence stem cell survival, proliferation, differentiation, and cell migration and polarity [10]. Before now, 19 distinct mammalian Wnt proteins have been identified [11]. They belong to a large group of secreted cysteine-rich proteins that are post-translationally modified by glycosylation and acylation. These modifications are required for the secretion of Wnts and for their full biological activity, respectively [12]. Glycosylated and palmitoylated Wnt molecules are subsequently bound to the Wntless (WLS) proteins, guided to the cell membrane of the Wnt-secreting cell, and released to the extracellular space [13]. The Wnt proteins activate different branches of Wnt signaling, three of which have been best characterized: the canonical-Wnt $/ \beta$-catenin — pathway, and two non-canonical pathways-the planar cell polarity (PCP) pathway and the Wnt/calcium $\left(\mathrm{Ca}^{2+}\right)$ pathway [14,15]. Various Wnt proteins, such as Wnt1, Wnt2b or Wnt3, initiate the canonical Wnt signaling branch, while Wnt5a and Wnt11 typically activate non-canonical Wnt signaling [16]. However, some Wnt proteins may play a dual role and activate both the canonical and non-canonical cascades simultaneously, in a tissue-specific manner $[17,18]$. In addition, non-canonical Wnts are able to antagonize the $\mathrm{Wnt} / \beta$-catenin functions, and their balance thus allows the regulation of both the proliferation and differentiation of progenitor cells [19].

The canonical Wnt pathway regulates the stability of its key mediator $\beta$-catenin, which has a dual role in the cell. In epithelial cells, it plays a structural role in cell-cell adhesion. As a component of a protein complex with cadherins, the protein forms adherent junctions [20], while in a complex with $\alpha$-catenin, it also interacts with the cytoskeleton [21]. On the other hand, free cytoplasmic $\beta$-catenin acts as an intracellular signal transducer in order to influence gene transcription [22], and exerts its full influence on the self-renewal and proliferation of NS/PCs [23]. In the absence of a Wnt signal, a multi-component, so-called $\beta$-catenin destruction complex is formed in the cytoplasm. It is composed of scaffolding proteins adenomatous polyposis coli (APC) and axis inhibition (AXIN), together with protein kinases glycogen synthase kinase $3 \beta$ (GSK3 $\beta)$ and casein kinase 1 (CK1). Once $\beta$-catenin meets the destruction complex, it is phosphorylated at the $\mathrm{N}$-terminal sequence by the kinases. Phosphorylated $\beta$-catenin is subsequently ubiquitinated by ubiquitin E3 $\beta$-transducin repeats-containing protein $(\beta-\operatorname{Tr} C P)$, and eventually degraded in the proteasome. This leads to low intracellular levels of the protein, and leaves the nuclear transcription factors of the pathway T-cell factor/lymphoid enhancer-binding factor (TCF/LEF) silenced by co-repressors groucho and transducin-like enhancer of split (TLE) [24]. Nevertheless, once a Wnt protein exerts its ligand function and attaches to the frizzled (FZD) receptor and its co-receptor low-density lipoprotein receptor-related protein 5/6 (LRP5/6), the FZD-LRP receptor complex binds the dishevelled (DVL) protein. This protein, together with LRP phosphorylated at its intracellular domain, recruits AXIN to the plasma membrane [25]. These events lead to the disassembly of the destruction complex and, as a result, stabilized $\beta$-catenin accumulates in the cytoplasm, and is thereafter translocated to the nucleus. Moreover, another mechanism bypassing the AXIN protein has been recognized, where LRP6 directly inhibits GSK3 $\beta$ and thus stabilizes $\beta$-catenin independent of the destruction complex [26]. In the nucleus, $\beta$-catenin binds to the effector transcription factors from the TCF/LEF family, subsequently binding other co-activators in order to initiate transcription of the Wnt-responsive genes. Some of the genes influence the progression of the cell cycle (e.g., cyclin D1) and are characteristic of adult stem cells (e.g., leucine-rich repeat-containing G protein-coupled receptor 5, LGR5) [27], while other Wnt target genes negatively regulate the pathway (e.g., AXIN) [28]. For further information on canonical Wnt signaling, please visit the Wnt homepage [29].

Unlike the canonical Wnt pathway, the non-canonical PCP pathway orchestrates the orientation of the cells that reside in the tissue [30,31]. At the outset of signaling, Wnt ligands bind to the FZD receptor and receptor tyrosine kinases of the RYK and ROR families [32] to subsequently transduce the signal to DVL. The relay does not involve $\beta$-catenin, but instead is mediated by the small GTPase Ras homolog family member A (RhoA) and the Rac family small GTPase 1 (RAC1). RhoA activation also 
requires the DVL-associated activator of morphogenesis 1 (DAAM1) protein, and via Rho-associated kinase (ROCK), it mediates actin polymerization. RAC1, together with another GTPase, CDC42, further activates c-Jun N-terminal kinase (JNK), which is also implicated in the rearrangement of the cytoskeleton. Moreover, JNK phosphorylates transcription factor C-JUN, which forms a heterodimer with the activator protein 1 (AP1) transcription factor and thus controls cell proliferation, differentiation and apoptosis [33].

The Wnt/Ca ${ }^{2+}$ pathway primarily regulates cell adhesion and motility. Upon Wnt signaling activation, the signal is relayed through phospholipase C (PLC), which hydrolyzes phosphatidylinositol 4,5-bisphosphate (PIP2) to inositol trisphosphate (IP3) and diacylglycerol (DAG). IP3 triggers $\mathrm{Ca}^{2+}$ release from the endoplasmic reticulum. Elevated intracellular $\mathrm{Ca}^{2+}$ concentration together with DAG activate $\mathrm{Ca}^{2+}$-dependent enzymes, such as protein kinase C (PKC), calcineurin, and $\mathrm{Ca}^{2+}$ /calmodulin-dependent protein kinase II (CaMKII). While PKC downstream signaling promotes cytoskeleton remodeling in the PCP pathway [34], calcineurin activates the nuclear factor of activated T-cells (NFAT) transcription factor, which further regulates cell proliferation and differentiation. The CaMKII-dependent branch of the pathway activates the nemo-like kinase (NLK), which antagonizes the Wnt/ $\beta$-catenin pathway [35]. The main components of the three Wnt branches are outlined in Figure 1.
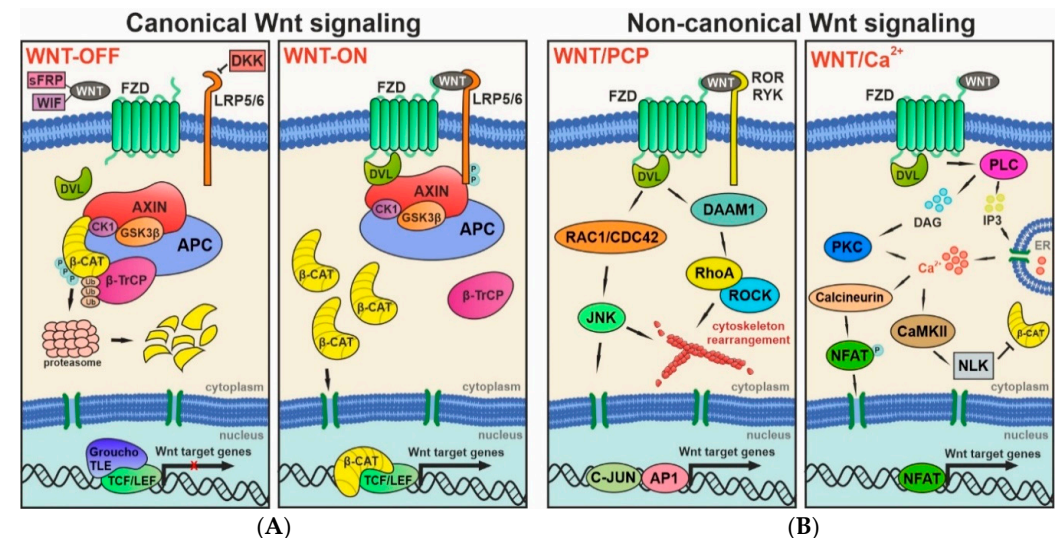

Figure 1. Overview of the canonical and non-canonical Wnt signaling pathways. (A) $\beta$-catenin-dependent signaling is activated by binding of a canonical Wnt ligand to the frizzled (FZD) receptor and the low-density lipoprotein receptor-related protein 5/6 (LRP5/6) co-receptor. Subsequently, $\beta$-catenin is released from the destruction complex and translocated to the nucleus, where it forms a complex with the T-cell factor/lymphoid enhancer-binding factor (TCF/LEF) proteins in order to activate transcription of the Wnt-responsive genes; (B) Activation of the non-canonical- $\beta$-catenin-independent-Wnt signaling branches influences cell properties and results in transcription of alternative Wnt target genes. In addition, in some cells non-canonical signaling inhibits $\beta$-catenin-mediated transcription. A more detailed description of the pathways is given in the text. Abbreviations: AP1, activator protein 1 ; APC, adenomatous polyposis coli; AXIN, axis inhibition; $\beta$-CAT, $\beta$-catenin; $\beta$-TrCP, $\beta$-transducin repeats-containing protein; C-JUN, transcription factor C-JUN; $\mathrm{Ca}^{2+}$, calcium; CaMKII, $\mathrm{Ca}^{2+} /$ calmodulin-dependent protein kinase II; CDC42, GTPase CDC42; CK1, casein kinase 1; DAAM1, DVL-associated activator of morphogenesis 1; DAG, diacylglycerol; DKK, dickkopf; DVL, dishevelled; ER, endoplasmic reticulum; GSK3 $\beta$, glycogen synthase kinase $3 \beta$; IP3, inositol trisphosphate; JNK, c-Jun $\mathrm{N}$-terminal kinase; NFAT, nuclear factor of activated T-cells; NLK, nemo-like kinase; P, phosphorylation; PCP, planar cell polarity; PKC, protein kinase C; PLC, phospholipase C; RAC1, Rac family small GTPase 1; RhoA, Ras homolog family member A; ROCK, Rho-associated kinase; ROR, receptor tyrosine kinase ROR; RYK, receptor tyrosine kinase RYK; sFRP, secreted FZD-related proteins; TLE, transducin-like enhancer of split; Ub, ubiquitination; WIF, Wnt inhibitory factor.

Additionally, Wnt signaling may be suppressed or regulated by a plethora of extracellular proteins. Secreted FZD-related proteins (sFRPs) and Wnt inhibitory factor (WIF) both bind to Wnt proteins, 
and thus chelate the ligands that may potentially activate Wnt signaling. Therefore, they act as antagonists for both the canonical and non-canonical pathways [36]. Another class of Wnt inhibitors belongs to the dickkopf (DKK) family. These proteins have been shown to block Wnt signaling by disrupting the FZD-LRP receptor complex [37], thus specifically antagonizing the Wnt/ $\beta$-catenin pathway [38]. All the aforementioned extracellular molecules affect Wnt signaling in a short-range manner and inhibit only the cells residing in the close vicinity of the ligand-secreting cell [39]. Moreover, the interpretation of the differentially expressed components of signaling pathways may be challenging, as many of them do not act separately, and rather share multiple pathways. In addition, Wnt signaling also interacts with other pathways that are involved in NS/PC fate specification and adult tissue homeostasis, such as sonic hedgehog (Shh) signaling. Wnt and Shh both influence NS/PC maintenance, proliferation and differentiation $[40,41]$. It has been shown that the coordination of Wnt and Shh signaling via the glioma-associated oncogene 3 (GLI3) protein alters the type of NS/PCs-derived neurons [42]. Additionally, GLI1 and GLI2 both inhibit Wnt signaling through positive regulation of the Wnt blocker sFRP1, whereas, concurrently, $\beta$-catenin and TCF/LEF can enhance the transcriptional activity of the GLI1 protein and thus promote Shh signaling [43].

\section{Wnt Signaling in Adult Neurogenesis of the Healthy Brain}

The Wnt signaling pathway in the adult brain, as in many other tissues, is indispensable in the regions where new cells are generated. In the healthy CNS, Wnt signaling plays multiple roles in the self-renewal, neurogenesis and homeostasis of neural stem cells (NSCs). Adult NSCs undergo asymmetric division to maintain a pool of pluripotent cells, while providing progenitor cells capable of differentiating to neuronal and glial cell populations. Recent studies provide evidence that these processes require precise regulation of molecular signals in order to prevent the gradual loss of postnatal NSCs, and ensure continuous neurogenesis in the brain (reviewed in Reference [23]).

In the mammalian brain, adult neurogenesis is limited to two distinct regions where doublecortin (DCX)-positive putative neuroblasts occur-the dentate gyrus (DG) of the hippocampus (subgranular zone, SGZ) [44] and the vicinity of the walls of the lateral ventricles (LVs; subventricular zone, SVZ) [45]. In comparison to embryonic development, the number of postnatal neuroblasts in these areas is very low, and further declines with age. Moreover, the controversial results of recent studies have given rise to doubts regarding whether substantial neurogenesis actually occurs in the SGZ of the adult human brain [46,47]. In any case, the possibility of deciphering how the neuroblasts in this region actually contribute to the pool of mature neurons, and whether they are involved in the brain activity for a long period of time, is limited within human tissue. Studies in experimental animals, especially mice, provide a more detailed look into adult neurogenesis in both areas. In brief, adult NSCs are mainly quiescent and only a small portion of them is activated, creating an equilibrium state that protects the tissue from exhaustion of the NSC pool. Activated NSCs give rise to proliferating neural progenitor cells (NPCs), differentiating to neuroblasts, which gradually mature to terminally differentiated neurons. However, many studies show the existence of different types of NSCs that have the potential to differentiate to distinct types of neurons and, in addition, to several types of glial cells. Such NSCs differ in localization within the SVZ and the SGZ, as well as in the expression of some transcription factors upon their activation [48,49]. However, they share many common markers, such as glial fibrillary acidic protein (GFAP), nestin, and SRY-box transcription factor 2 (Sox2), and they are in contact with blood vessels (reviewed in Reference [50]).

Adult neurogenesis is a process including the proliferation and specification of neural progenitors, their differentiation to neurons, and neuron migration and integration into the existing circuits. The active canonical Wnt pathway, together with the removal of Sox2-mediated repression, leads to the activation of quiescent NSCs and drives their proliferation, most likely through the expression of the gene encoding transcription factor neurogenic differentiation 1 (NeuroD1) and through the activation of long interspersed nuclear elements 1 (LINE1) [51]. Wnt signal is produced by adult hippocampal progenitors and astrocytes near the SGZ [52,53], and adult Wnt7 knock-out mice 
display decreased proliferation and, moreover, decreased Dcx-expressing neuroblasts in both the hippocampus and the SVZ [54]. In the SVZ, retrovirus-mediated expression of a stabilized form of $\beta$-catenin was shown to induce proliferation of NPCs [55]. Conversely, the loss of disrupted in schizophrenia 1 gene (Disc1) has been shown to reduce the proliferation of adult NPCs in the hippocampus through Wnt/ $\beta$-catenin inhibition [56]. Besides NS/PC maintenance and proliferation, Wnt7 has been shown to promote neuronal differentiation and maturation via $\beta$-catenin/neurogenin 2 signaling in the DG [57]. In addition, $\beta$-catenin-Tcf/Lef signaling enhanced neuronal differentiation in this region through the expression of the prospero-related homeodomain transcription factor 1 (Prox1) [58]. Moreover, enhanced $\beta$-catenin/homeodomain interacting protein kinase 1 (Hipk1) resulted in decreased proliferation and increased differentiation of NS/PCs in the SVZ [59], indicating that the precise balancing of the $\mathrm{Wnt} / \beta$-catenin signaling level is indispensable in maintaining long-term neurogenesis in the adult brain. In addition, the gradual loss of neurogenesis related to aging is associated with the attenuation of the canonical Wnt signaling pathway, as illustrated by the decreased expression of Wnt3 ligands in the DG in aged mice [60]. The age-related decrease of neurogenesis has also been linked to the expression of Wnt inhibitory molecules in both the hippocampus, where Dkk1 [61] and sFRP3 [62] were expressed, and the SVZ, where the expression of wild-type p53-induced phosphatase 1 (Wip1) and Dkk3 was observed [63]. Strikingly, the loss of Dkk1 expression restored neurogenesis and improved the cognitive functions of aged mice [64]. On the other hand, induced Dkk1 expression in the adult hippocampus resulted in the loss of neuronal synapses and long-term memory deficits [65]. Notably, the production of Wnt inhibitory molecules in healthy adult tissue is likely to be regulated by multiple pathways whose potency decreases with age, as shown on the p38 mitogen-activated protein kinase (MAPK) pathway in the adult SVZ [66].

The non-canonical Wnt signaling pathway also plays a role in adult neurogenesis, as evidenced by behavioral changes and reduced long-term memory in mice deficient of JNKs $[67,68]$. Constitutive expression of non-canonical ligand Wnt5a was documented in the adult hippocampus. Through the JNK pathway, non-canonical Wnt plays a role in neuronal differentiation and synapse modulation $[69,70]$. FZD5/JNK signaling is involved in the formation of the neuronal polarity and development of neuronal processes [71]. A role of the downstream c-Jun effector AP1 in neuronal maturation was shown previously [72]; moreover, Wnt/JNK/AP1 signaling promoted differentiation to neurons from induced pluripotent stem cells (iPSCs) in vitro in a $\beta$-catenin-independent manner [73]. A more recent study then identified the Wnt/JNK and Wnt/CaMKII signaling pathways (activated by the Wnt5a ligand) as essential players in the neuronal differentiation of NPCs in the adult hippocampus [74]. In contrast, both canonical and non-canonical Wnt ligands-Wnt3a and Wnt5a-increased the level of $\beta$-catenin and, subsequently, NPC proliferation and differentiation in SVZ-derived cells [75]. Moreover, adaptor protein ATPase $\mathrm{H}^{+}$transporting accessory protein 2 (ATP6AP2) was identified as a regulator of the cell response from Wnt/ $\beta$-catenin to Wnt/PCP signaling in adult NSCs isolated from the hippocampus [76]. In addition, the attenuation of non-canonical Wnt signaling promoted the activation of quiescent NCSs in the adult SVZ [77]. All of these observations suggest that both the canonical and non-canonical Wnt pathways are required for the production of mature neurons, and the mutual balancing of these often opposing pathways is necessary to maintain neurogenesis in the adult brain.

\section{Wnt Ligand Expression/Sensing in Particular Cell Types of the Adult Neurogenic Regions}

Considering the activity of the Wnt signaling pathways in the neurogenic regions of the adult brain, it is necessary to distinguish the Wnt-signal-producing cell types from the Wnt-receiving cells in the region. As in other adult tissues with homeostatic capacity (e.g., the intestine, stomach or skin; reviewed in Reference [78]), NSCs in the adult brain need their niche that produces the signals essential for NSC maintenance and proliferation (Figure 2). The adult neurogenic niche includes glial cells, specifically astrocytes and NG2 glia, and also, in the case of the SVZ, ependymal cells. Glial cells represent a large proportion of cells, between one and two thirds of all cells in the adult mammalian brain; in humans, the number of neurons and glial cells is almost equal [79]. Although glia were 
previously mainly considered as supportive cells, studies over the last 20 years have clearly shown their indispensable role in adult neurogenesis under physiological conditions and in brain tissue regeneration after injury.

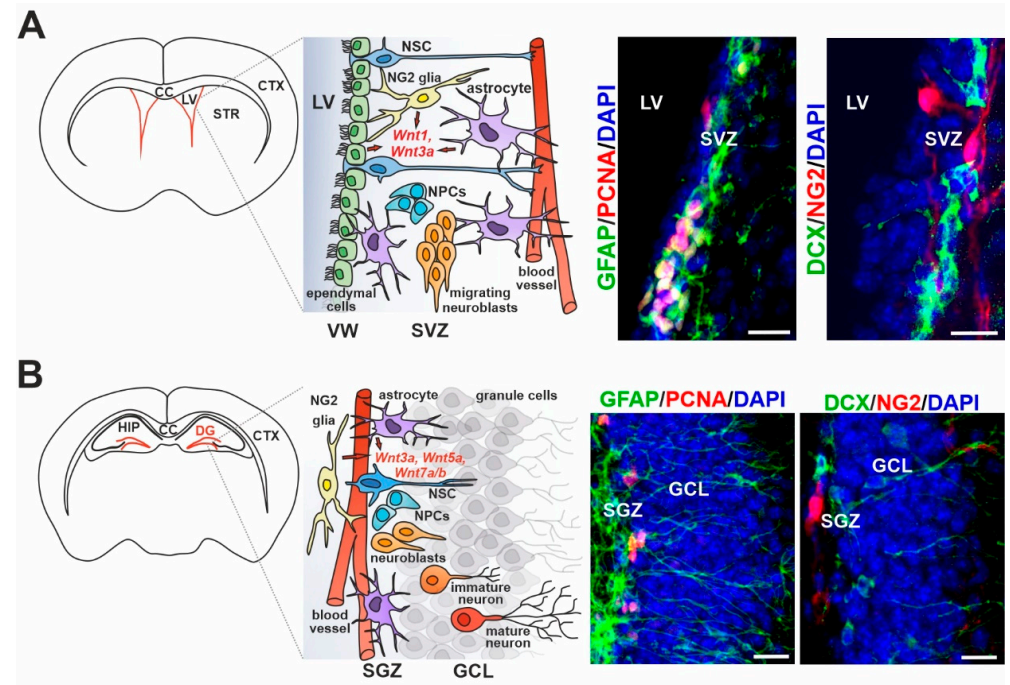

Figure 2. Neurogenic niches of the adult mammalian brain. Schematic diagrams illustrating the main cellular components within the neurogenic niche in the (A) subventricular zone (SVZ) of the lateral ventricles (LVs) and (B) dentate gyrus (DG) of the hippocampus (HIP) containing the neurogenic niche in the subgranular zone (SGZ), and representative immunofluorescence images of the corresponding regions showing the main markers of cell types indicated in the illustrated schemes. The neuronal lineage in both compartments is represented by neural stem cells (NSCs), neural progenitor cells (NPCs) and migrating neuroblasts. In addition, neuronal maturation is shown in the granule cell layer (GCL) adjacent to the SGZ. Glial cells, represented by astrocytes and neuron-glial antigen 2 (NG2)-positive glia in both regions, and by ependymal cells constituting the ventricular wall (VW) of the LVs, release Wnt ligands (in red color) in order to activate quiescent NSCs and mediate their proliferation/differentiation. Glial fibrillary acidic protein (GFAP) represents NSCs and a subpopulation of astrocytes; proliferating cell nuclear antigen (PCNA) marks proliferating progenitors; doublecortin (DCX)-positive cells identify both neuroblasts and immature neurons; NG2 is present in NG2 glia; 4',6-diamidino-2-phenylindole (DAPI) stains cell nuclei. Note that the magnified field and DG histology in panel B are rotated approximately $90^{\circ}$ counterclockwise compared to the scheme of the frontal section. Scale bar: $15 \mu \mathrm{m}$. Abbreviations: CC, corpus callosum; CTX, cortex; STR, striatum.

Astrocytes are present in all parts of the brain and provide many supporting functions, such as the maintenance of tissue homeostasis and the blood-brain barrier (BBB), but they also participate in the tripartite synapses (reviewed in Reference [80]). A subset of GFAP-producing astrocytes is crucial for neuronal health and integrity, as their removal leads to severe neuronal degeneration [81,82]. Astrocytes in the adult neurogenic niches serve as a source of GFAP-positive NSCs, and share the functional characteristics of glial cells and multipotent progenitors [83]. In the SGZ, astrocytes promote NSC proliferation and neuronal differentiation [52] by producing the canonical Wnt3a ligand in cooperation with bone morphogenetic proteins 2 and 4 (BMP2/4) [84]. In the SVZ, astrocytes were shown to produce Wnt7a, which stimulates the canonical branch of the pathway [85]. Astrocytes outside the neurogenic niche in the healthy adult brain appear to fulfil different functions, and show neither progenitor properties nor neurogenic potential. However, their properties change after traumatic brain injury and stroke (reviewed in Reference [86]).

NG2-expressing glial cells, also called polydendrocytes, are the most recently discovered type of glial cells [87]. NG2 glia are highly proliferative and harbor several stem cell characteristics. As precursor cells, they mainly generate myelinating oligodendrocytes in cell culture and in the healthy adult brain, and are therefore often called OPCs. Nevertheless, it has been discovered that 
NG2 glia form synapses with neurons and are able to receive their signal, although they themselves are not capable of generating action potentials and transmitting signals to other cells (reviewed in Reference [80]). Importantly, these cells have a high repopulation capacity [88,89] that declines with age $[90,91]$. The chronic loss of this cell type in the white matter of the cerebral cortex resulted in reduced oligodendrogenesis, which subsequently led to motor dysfunctions [92]. Interestingly, their ablation in the prefrontal cortex caused deficits in excitatory glutamatergic neurotransmission and astrocytic glutamate uptake, and led to depressive-like behaviors in mice [93], indicating more than one role for NG2 glia in the adult brain. Furthermore, in vitro studies revealed the multipotent capacity of these cells, as they were able to differentiate to functional neurons or astrocytes [94,95]. Multiple follow-up studies using genetic fate mapping have excluded the differentiation of NG2 glia to cell types other than oligodendrocytes (and NG2 glia in order to repopulate their pool) in the adult brain [96-98], but recent research has indicated that this potential may be activated in the event of traumatic or ischemic injury [99-102].

The expression of the platelet-derived growth factor receptor $\alpha$ (PDGFR $\alpha)$ is essential for the differentiation of NG2 glia to oligodendrocytes [103], and through the activation of the Wnt/ $\beta$-catenin pathway it also potentiates the proliferation of polydendrocytes $[104,105]$. Surprisingly, several studies have demonstrated that $\mathrm{Wnt} / \beta$-catenin signaling negatively regulates oligodendrogenesis during embryonic development $[106,107]$ and, in cooperation with the BMP signaling pathway, delays oligodendrocyte maturation in vitro in postnatal rodent NG2 glia [108,109]. On the other hand, Wnt-negative regulator APC has been reported to be transiently enhanced in newly differentiated oligodendrocytes and, moreover, it co-localized with Wnt effector TCF4 in the same cell population, regulating oligodendrogenesis in both a $\beta$-catenin-dependent and a $\beta$-catenin-independent manner [110]. Furthermore, the recombinant canonical Wnt3a ligand potentiated differentiation of adult NG2 glia expressing Olig2 in cell cultures isolated from the adult SVZ without affecting the neurogenesis from these cells [111]. Consistently, GSK3 $\beta$ inhibition (resulting in Wnt/ $\beta$-catenin signaling activation) stimulated the expression of myelin basic protein (MBP) and oligodendrocyte maturation in vitro and in vivo [112,113]. In addition, fluorescence-activated cell sorting (FACS) analysis revealed that Wnt3, the most abundant Wnt ligand in the adult SVZ, is predominantly expressed by NG2 glia, suggesting a positive feedback loop driving the generation of this cell type from adult SVZ NSCs [111].

NS/PCs in both neurogenic regions - the SVZ and the SGZ of adult mice-were shown to express the Wnt/ $\beta$-catenin-responsive gene Axin2 [114], and many other studies reported active Wnt/ $\beta$-catenin signaling in adult NS/PCs present in these regions [55,56,58,59]. Transplantation experiments showed that extrinsic sources of the signal from the neurogenic niche are essential for the maintenance of NSCs, as well as for the neuronal fate and specification of neuronal subtypes [115-117]. In fact, adult NS/PCs represent a diverse pool of cells with high plasticity, and their surrounding niche is what determines their future characteristics. Consequently, adult tissue is able, although to a limited extent, to respond to its current needs, and is capable of at least partial regeneration after traumatic injury (reviewed in Reference [118]). In addition, many studies suggest that adult NSCs are not only the recipients of the Wnt signal, but they might also secrete Wnt molecules. The canonical Wnt ligands Wnt3 and Wnt7a were found in adult hippocampal NPCs [52,53], and high expressions of non-canonical Wnt ligand Wnt5a and canonical ligands Wnt7a and Wnt7b were found in vitro in NS/PCs isolated from the neonatal SVZ. Importantly, enhanced levels of Wnt/ $\beta$-catenin signaling resulted in increased differentiation to neuronal precursors, and conversely, decreased canonical Wnt signaling potentiated gliogenesis [119]. This is consistent with a more recent study in which the $\mathrm{Wnt} / \beta$-catenin pathway suppressed astrogliogenesis during spinal cord development in vivo [120]. On the other hand, transcriptional profiling did not reveal the expression of any Wnt ligands in NSCs isolated from the adult SVZ, and conversely, Dkk3 was highly produced in NSCs. This observation could be attributed to the predominant quiescent state of adult NSCs in the SVZ [121]. In the same study, Azim and colleagues found expressions of Wnt ligands in the surrounding neurogenic niche, where 
Wnt7b was localized in glial cells. In addition, the enrichment of mRNAs encoding several components of the Wnt pathway was recorded in endothelial cells found in the circumjacent tissue [121]. As shown recently, Wnt/ $\beta$-catenin signaling in NSCs plays a role primarily in maintaining the BBB [122,123]. However, the role of Wnt signaling in adult neurogenesis is still enigmatic.

Ependymal cells are present only in the SVZ, constituting a multiciliated lining of the LVs. They form pinwheel-like structures in order to surround the apical processes of NSCs attached to the basal lamina of the LVs [124]. Their structural function seems to be essential for the maintenance and differentiation of NSCs and the migration of their progeny, as evidenced by reduced neurogenesis and impaired neuroblast migration upon the loss of ependymal cells in the SVZ [125]. The expression of Wnt ligands Wnt1, Wnt3, Wnt5a and Wnt11, and several Wnt signaling components, was observed in the ependymal layer of the neurogenic region of the spinal cord surrounding the central canal [126,127]. Moreover, experiments based on the detection of the Wnt-responsive gene Axin2 revealed the active Wnt/ $\beta$-catenin pathway in adult ependymal cells residing in the SVZ [114]. In addition, ependymal PCP induced by non-canonical Wnt/PCP signaling [128] is involved in neuronal migration, as motile cilia of ependymal cells generate cerebrospinal fluid (CSF) flow that guides newly generated neurons [129].

\section{Cerebral Ischemia}

Stroke is a major cause of death and disability worldwide, and based on its etiology, it can be either ischemic or hemorrhagic. Ischemic stroke is caused by a reduction in the cerebral blood flow, whereas hemorrhagic stroke is caused by intracerebral bleeding. In this review, we focus on ischemic stroke, since it is the predominant form, accounting for approximately $80 \%$ of all stroke cases [130]. Ischemia is characterized as a decrease in the blood flow, sufficient to affect normal cell functions. Brain tissue is extremely prone to ischemic injury due to its high energy demand, and even brief periods of ischemia can lead to serious damage and cell death [131].

Based on its extent and origin, ischemic brain injury may be subdivided into global cerebral ischemia (GCI) and focal cerebral ischemia (FCI). While FCI only affects a certain region of the brain, GCI is caused by decreased blood flow in the whole brain. Common causes of FCI are thrombosis and embolism, whereas GCI occurs after systemic hypoperfusion or asphyxia [131,132]. In the brain region affected by FCI, two zones are recognized. A zone of severe ischemic injury, the ischemic core, is characterized by low adenosine triphosphate (ATP) levels, high concentrations of glutamate and ions, and acidosis. Necrosis is the prevailing type of cellular death in this area. However, the severity of the damage decreases gradually with the distance from the core, in a region known as the ischemic penumbra. In this region, the residual blood flow from collateral arteries mitigates the conditions. A drop in ATP levels is milder, causing transient ischemic depolarization and ion shift in the penumbra, while glutamate concentration rises during the first hour after ischemia, but then declines to the physiological levels. The conditions during GCI are similar to those in the ischemic core [133].

The reduction in the blood flow leads to a deficit in glucose and oxygen in the brain tissue, thus damaging cellular energy metabolism. A quick depletion of ATP follows, and leads to the loss of the membrane potential and depolarization due to the failed maintenance of ionic gradients by ion pumps, followed by glutamate release from neurons. This ischemic pathway thus leads to the process known as glutamate excitotoxicity (reviewed in Reference [4]). The activation of glutamate receptors further increases intracellular concentrations of $\mathrm{Ca}^{2+}$, together with elevated intracellular concentrations of sodium $\left(\mathrm{Na}^{+}\right)$and chloride ions $\left(\mathrm{Cl}^{-}\right)$, followed by a passive influx of water and edema formation [134]. Simultaneously, the high concentration of $\mathrm{Ca}^{2+}$ leads to the activation of $\mathrm{Ca}^{2+}$-dependent enzymes, such as phospholipase $\mathrm{A}_{2}$ and cyclooxygenase. This results in the production of reactive oxygen species (ROS) and the subsequent damage of genomic DNA, proteins, lipids and the cell membrane [135]. One of the main targets of ROS are mitochondria. Radicals can induce the disruption of the inner mitochondrial membrane and further negatively affect ATP production. Moreover, damaged mitochondria release pro-apoptotic signals, leading to cell death [136]. 
Ischemic damage and processes occurring thereafter lead to neuroinflammation, in which glial cells, particularly microglia, but also astrocytes, are involved [137]. Moreover, the BBB is damaged after ischemic injury, loses its function, and becomes permeable for fluids and plasma elements [138].

In reaction to FCI, a structure known as the glial scar is formed. Within hours after ischemic injury, macrophages and microglia appear, and subsequently, NG2 glia emerge in the tissue surrounding the injured region within a few days after the insult. A permanent glial scar consists predominantly of astrocytes, but it also contains microglia and NG2 cells [101,139]. The formation of the glial scar is a process that occurs both in experimental animal models of stroke, and in humans [140]. A more detailed description of ischemic stroke and glial scar formation is provided elsewhere $[4,131]$.

\section{The Impact of Wnt Signaling on Different Cell Types during Ischemia}

Wnt signaling has been shown to play an important role after ischemic injury in the brain. The current treatment of ischemic stroke is limited to restoring the blood flow through the occluded artery [141]; however, Wnt signaling has been documented to affect various biological processes that might help with tissue recovery.

One such process might be the regeneration of brain vascularization. The activation of Wnt signaling by Wnt3a caused an increase in the BBB-like function of cultured human brain endothelial cells [123]. The Wnt7a and Wnt7b ligands, produced by neuroepithelium during the mouse brain development, were observed to target the vascular endothelium and stimulate formation of the BBB by activation of the canonical Wnt signaling pathway [142]. It is evident that this role of Wnt signaling is maintained in postnatal development [143]. Treatment of ischemic rats with compound porcine cerebroside and ganglioside injections led to the amelioration of the injury by promoting the cerebral blood flow, and simultaneously, an increased production of Wnt signaling pathway-associated proteins was noted. Taken together, the indicated results imply that Wnt signaling might play a role in the mitigation of impacts caused by cerebral ischemia [144].

Wnt signaling does not only impact the restoration of the blood flow after ischemic injury, but it has also been described as a neuroprotective agent. The concentration of the Wnt signaling pathway antagonist Dkk1 rose in the rat hippocampus after transient GCI, while restoration of the pathway protected hippocampal neurons against the damage caused by ischemia [145]. A similar phenomenon was observed in rats undergoing FCI. Moreover, neuronal damage caused by the middle cerebral artery occlusion (MCAO), a commonly utilized animal model of FCI, was reduced in mice with decreased expression of Dkk1 [146]. A possible explanation of this effect is that $\beta$-catenin regulates the expression of B-cell lymphoma 2 (Bcl2), a protein with anti-apoptotic properties [147]. Interestingly, post-conditioning with isoflurane reduced the infarction volume and apoptosis of neurons in rats, and this effect was linked to Wnt signaling activation [148]. Since elevated plasma levels of Dkk1 were observed in humans after stroke [149], we hypothesize that similar mechanisms might occur in the human brain.

Apart from its function in neuroprotection, Wnt signaling has been reported to play a role in nervous tissue regeneration after stroke. Many studies have reported that ischemic injury leads to increased neurogenesis in the SVZ and SGZ [150]. Since Wnt signaling increases neurogenesis in the healthy brain, it should be considered a possible contributor to ischemia-induced neurogenesis. Indeed, an increase in Wnt signaling, together with increased symmetrical division of NSCs, was observed after stroke in the SVZ, and blocking the Wnt pathway led to a drop in the number of neurospheres [151]. Moreover, Wnt3a administration led to a decreased infarction zone size. Furthermore, treatment with Wnt3a increased the expression of brain-derived neurotrophic factor (BDNF) and promoted the proliferation of neuroblasts in the SVZ. At 14 days after the onset of stroke, neuroblasts migrated to the peri-infarct region, and at 21 days after ischemic injury, increased numbers of newly generated neurons were observed [152]. In mice suffering from FCI in the striatum, the over-expression of Wnt3a led to increased proliferation of NSCs that later became mature neurons, improving motor functions 28 days after injury. Furthermore, Wnt3a over-expression in the SVZ caused an increase in the number of proliferating 
cells, accompanied by a reduction in size of the lesion two days after ischemia. Additionally, increased numbers of immature neurons in the striatum were observed [153]. Conversely, the inhibition of Wnt signaling by $\beta$-catenin-specific small interfering RNA (siRNA) after ischemic injury led to reduced numbers of proliferating progenitor cells, and both immature and mature neurons [154]. Interestingly, the level of $\beta$-catenin in the ischemic striatum was increased by the Bcl2 protein, and this increase was linked to enhanced neurogenesis. The neurogenic effect of $\mathrm{Bcl} 2$ was reversed by the administration of $\beta$-catenin siRNA, indicating the involvement of the Wnt signaling pathway [155]. A similar effect was observed in hemorrhagic stroke, where Wnt signaling activation promoted neurogenesis in the SVZ together with $\mathrm{Bcl} 2$ and $\beta$-catenin expression, suggesting that Wnt signaling plays similar roles in both ischemic and hemorrhagic stroke [156].

The neuroprotective and regeneration-stimulating effects of Wnt signaling after ischemic injury were also evidenced by the promotion of neurogenesis mediated by cadherin epidermal growth factor laminin G seven-pass G-type receptor 1 (CELSR1). The upregulation of CELSR1 mRNA was observed in the rat SVZ after ischemic stroke, and it led to increased neurogenesis and angiogenesis, mainly via the Wnt/PKC pathway [157]. Neuroglobin, an oxygen-binding globin protein known for its neuroprotective properties, was shown to increase neurogenesis in the mouse brain affected by transient FCI. Again, this effect was described to act at least partially via canonical Wnt signaling [158].

An insight into a native mechanism by which the damaged tissue increases Wnt signaling was obtained in in vitro cultures of adult rat NSCs under hypoxic conditions. Under these circumstances, increased levels of $\beta$-catenin and increased neurogenesis were observed. Simultaneously, hypoxia-inducible factor $1 \alpha$ (HIF1 $\alpha)$ expression was upregulated, and the inhibition of this factor counteracted hypoxia-induced expression of $\beta$-catenin [159]. A further insight into this mechanism was provided by Chen and colleagues, who reported that after ischemia-reperfusion injury in rats, peroxynitrite was produced, activating the proliferation and differentiation of NSCs via the upregulation of HIF1 $\alpha$ and Wnt signaling. However, higher doses of peroxynitrite were neurotoxic [160]. Another intrinsic factor that might play a role in the reaction of nervous tissue to ischemic injury is microRNA (miRNA)-148b, since its over-expression has been reported in the SVZ of the ischemic rat brain. The inhibition of this particular miRNA enhanced the expression of Wnt1 and $\beta$-catenin. Moreover, miRNA-148b inhibition caused increased proliferation of NSCs and their differentiation to neurons and astrocytes [161], suggesting that the ischemia-induced (over)expression of miRNA-148b had detrimental effects on the brain tissue, and might be a possible therapeutic target. Wnt signaling was also affected in mice with knock-out of the Ppm1d gene encoding Wip1 phosphatase. Animals of this mouse strain exhibited worsened functional recovery after ischemia, which was compensated for by pharmacological activation of the Wnt signaling pathway. This provided further understanding of Wnt-related mechanisms occurring in the nervous tissue after stroke [162]. A different Wnt-related mechanism affecting neurons and NSCs in the ischemic brain was associated with myeloperoxidase-dependent oxidative stress mediating decreased $\beta$-catenin levels after ischemic injury. Inhibiting myeloperoxidase with $\mathrm{N}$-acetyl lysyltyrosylcysteine amide counteracted Wnt signaling suppression, and led to increased numbers of NSCs and immature neurons in the cortex [163]. Additionally, long non-coding RNA maternally expressed gene 3 (Meg3) was found to act as a negative regulator of neurogenesis. Meg3 was increased after ischemia-reperfusion injury in rats, and reduced expression of this RNA molecule promoted neurogenesis, reduced the infarct area, and attenuated neuronal apoptosis and necrosis. Moreover, the effect of the decreased Meg3 levels was reversed by treatment with Dkk1, while the detrimental impact of Meg3 was reversed by lithium chloride ( $\mathrm{LiCl})$, a Wnt signaling activator [164]. Interestingly, NSCs were also affected by tissue plasminogen activator (tPA), a substance that is often used for ischemic stroke treatment to dissolve the thrombus. Inhibiting the tPA activity in primary cultures caused decreased neurite outgrowth-the same phenotype as observed in the knock-down of $\beta$-catenin or LRP5/6. Moreover, axon density was lower in the ischemic rat brain treated with transplanted NSCs with tPA knock-out, when compared to the brains treated with 
wild-type NSCs [165]. This suggests that tPA produced by NSCs might affect the ischemic tissue via the Wnt signaling pathway.

Taken together, there is strong evidence that Wnt signaling is crucial in stimulating NS/PC proliferation after ischemic injury. Strikingly, Morris and co-workers showed that the expression of Wnt genes was not upregulated in the SVZ of rats after ischemic injury [166]. Contrary to this observation, another study reported increased cell numbers with active Wnt signaling in the SVZ after stroke [151]. This discordance might be due to the different regions examined or the use of different methods. While Morris and colleagues used cultured NSCs from ischemic rats, and analyzed total RNA obtained from these cells using reverse transcription polymerase chain reaction (RT-PCR) [166], Piccin and Morshead evaluated cells with active Wnt signaling in brain slices acquired from transgenic mice producing the $\mathrm{Wnt} / \beta$-catenin-reporter, thus visualizing the canonical Wnt signaling activity [151]. In contrast to both these results, Western blotting showed decreased levels of the $\beta$-catenin protein in the mouse brain three days after MCAO [163]. A possible explanation for such discrepancy might be the fact that the whole ischemic hemisphere was used by Yu and colleagues. Nevertheless, the majority of studies agreed on the importance of Wnt signaling in neurogenesis after ischemic injury, and described tissue-detrimental effects of Wnt pathway inhibition on the nervous tissue. Since the behavior of the damaged tissue seems to be very complex, to predict reactions of various cell types on the Wnt stimulus might be quite complicated.

Although NSCs benefit from the activation of the Wnt pathway, the situation is more intricate when it comes to astrocytes. It has been suggested that canonical Wnt signaling is increased in this cell type after ischemic injury. However, its role was linked to post-ischemic seizures, in which astrocytes participate. Interestingly, the inhibition of Wnt signaling in these cells after ischemic injury decreased the otherwise elevated susceptibility to seizures, indicating a possibly detrimental role of Wnt signaling in astrocytes [167]. Additionally, astrocytes have been observed to play a neuroprotective part in ischemic injury via the production of Dkk3, an atypical inhibitor of Wnt signaling. The protective effect was probably mediated by vascular endothelial growth factor (VEGF), and led to increased survival of both neurons and astrocytes [168]. Conversely, a potentially beneficial impact of Wnt signaling activation on astrocytes was observed after treatment with Wnt3a. Ischemic mice treated with this Wnt exhibited higher numbers of astrocytes with the protective phenotype, A2 astrocytes, while the number of astrocytes with the toxic phenotype-A1 astrocytes-was lower [169]. Generally, the effect of Wnt signaling on astrocytes after ischemic injury is still not well documented, and it therefore deserves further examination.

Wnt signaling also influences the reaction of microglia to ischemic conditions. Oxygen-glucose deprivation caused a decrease in the Wnt1 expression in microglial cells. Remarkably, treatment with Wnt1 had a beneficial effect on microglial survival, while the inhibition of Wnt1 increased their apoptosis [170]. Additionally, treating ischemic mice with Wnt signaling activator TWS119 unveiled an effect of the pathway on the microglial phenotype. The microglia of untreated ischemic mice were activated and shifted towards the pro-inflammatory phenotype, whereas the microglia of TWS119-treated mice showed the anti-inflammatory phenotype [171]. Similar results were observed after treatment with Wnt3a, which suppressed the expression of the markers of pro-inflammatory microglial phenotype and potentiated the anti-inflammatory microglial phenotype after ischemic injury. Moreover, the treatment with Wnt3a led to an overall decrease in microglia activation after stroke [169]. Another ligand from the Wnt family, Wnt5a, was produced by astrocytes, and was able to elicit a pro-inflammatory microglial response. This mechanism appeared to act via the $\mathrm{Wnt} / \mathrm{Ca}^{2+}$ pathway, independently of $\beta$-catenin. It is evident that these results provided useful insights into the pro-inflammatory activation of microglia; however, the relevance of the Wnt pathway-microglia crosstalk in the injured brain has not been investigated [172].

The beneficial effects of Wnt signaling were also observed in the cells of oligodendroglial lineage. Myelin repair in the ischemic penumbra was increased after treadmill exercise, and this effect was abolished after the treatment with Wnt signaling inhibitor XAV939, suggesting a possible role of active 
Wnt signaling in NG2 glia-cells known for their role in remyelination [173]. The differentiation of these cells to myelinating mature oligodendrocytes was also enhanced by the trophic factor tissue inhibitor of metalloproteinases 1 (TIMP1). The protein acted by increasing $\beta$-catenin signaling via protein kinase B (Akt) activity. Interestingly, the Wnt7a ligand counteracted the effects of TIMP1 on NG2 glia differentiation, suggesting the convergence of these two pathways [174]. Apart from their role in remyelination, NG2 glia were also observed to affect the BBB function. The transplantation of these cells promoted neurological recovery, decreased the infarct volume and brain edema after ischemic injury, and sustained the integrity of the BBB via activating the canonical Wnt signaling pathway [175].

\section{The Potential of Wnt Pathway Modulation in the Ischemic Stroke Therapy}

In an effort to find a new, more effective treatment for ischemic stroke that would improve the patients' long-term prognosis and reduce the adverse health consequences, many experimental approaches "came into play". Some of these approaches, such as treatment with allogeneic mesenchymal bone marrow cells or hyperbaric oxygen therapy, are already being tested in clinical trials (for more information on ongoing clinical trials, please visit the database of privately and publicly funded clinical studies [176]).

In addition to the pharmacological approach, which supports thrombolysis in order to prevent oxygen and nutritional deprivation, the cell-based therapy is a frequently explored possibility. As the neurogenic capacity of NSCs has already been demonstrated beyond doubt, many studies tested the transplantation of embryonic NSCs into the injured brain area. Importantly, several studies, performed not only on rodents but also on experimental pigs and monkeys, have shown the ability of transplanted NSCs to differentiate to long-surviving neurons. Another option is the transplantation of mesenchymal stem cells (MSCs), usually derived from the bone marrow. The disadvantage of these approaches lies in the induction of an immune response in the recipient. A possible solution to this obstacle seemed to be the use of NSCs derived from iPSCs. However, the generation of iPSCs is time-consuming, and their usage is associated with a risk of cancer; both phenomena greatly complicate this therapeutic approach (reviewed in Reference [177]). Since the Wnt signaling pathway promotes NS/PC proliferation and neurogenesis, the molecular support for the patient's own neurogenesis through Wnt modulatory agents immediately after ischemic stroke comes into consideration as a promising therapy. In fact, some previously proposed methods of stroke treatment might activate Wnt/ $\beta$-catenin signaling. For example, the neuroprotective function of the melanocortin $\mathrm{MC}_{4}$ receptor agonists in neurodegenerative disorders, including ischemic stroke (reviewed in Reference [178]), was linked to the upregulated Wnt and Shh signaling [179]. The cross-talk between these two signaling pathways occurs at multiple subcellular levels. Thus, a deeper understanding of their interactions could be utilized in the search for new chemical substances showing therapeutic potential. A similar positive effect of $\mathrm{Wnt} / \beta$-catenin signaling on the reduction of neurological defects was demonstrated after administration of the non-steroid anti-inflammatory agent sulindac in adult rats after MCAO [180], or with glucagon-like peptide 1 (GLP1) analog liraglutide [181]. The latter is currently used in the treatment of type 2 diabetes mellitus and obesity. Additionally, hyperbaric oxygen therapy, which is used in decompression sickness or long-lasting wound treatment, also showed neuroprotective effects after stroke. An increase in neurogenesis and neurological functions, observed after treatment with hyperbaric oxygen, was linked to the upregulated HIF1 $\alpha$ levels and, consequently, to increased $\beta$-catenin stability [182]. Moreover, the hyperbaric oxygen therapy promoted the differentiation of NSCs not only to neurons, but also to oligodendrocytes, and this effect was attenuated by Wnt signaling inhibitors [183]. Interestingly, Alpina officinarum-derived flavonoid galangin improved neuronal survival in mice after MCAO. The neuroprotective effect on the neurovascular unit was mediated by the HIF1 $\alpha$ /VEGF and Wnt/ $\beta$-catenin pathways [184]. Similarly, other plant derivatives, such as phenolic glycoside gastrodin and iridoid glycoside cornin, inhibited apoptosis and induced Wnt3a expression [185], and increased angiogenesis and Wnt5a expression [186], respectively, in the ischemic region of the mouse brain. Strikingly, electrical stimulation or electro-acupuncture, used in traditional 
Chinese medicine for the prevention and treatment of stroke, also seems to stimulate the proliferation of NSCs via the canonical Wnt pathway. Surprisingly, this therapy reduced the cerebral infarct volume and alleviated subsequent neurological deficits [187]. The effect of the canonical Wnt signaling pathway on the CNS is mainly associated with cell proliferation, migration and differentiation, as well as with the regulation of inflammation after acute injury (reviewed in Reference [188]). It is therefore a matter of discussion to what extent the amelioration of the pathological changes provoked by ischemic stroke is directly related to the activation of the Wnt pathway. Alternatively, increased Wnt signaling might be "a side effect" of the anti-inflammatory and pro-proliferative processes triggered in the damaged tissue.

Interestingly, several Wnt inhibitors, including Dkk proteins or miRNAs, appear to be produced in the adult brain after stroke, and contribute to neuronal degradation $[145,161]$. The suppression of these negative Wnt pathway regulators could "unlock" or "restart" the neurogenic potential of the adult brain, and thus contribute to the regeneration of the ischemic brain regions. Estrogen hormonal therapy suppressed Dkk1 expression in the tissue, and thus promoted the Wnt pathway's activity when administered shortly after ischemic injury. Such therapy also has some disadvantages; namely, the endogenous estrogen level may play an important role. It is not uncommon for postmenopausal women to fall into a state of estrogen deficiency, and thus the brain's sensitivity to estrogen is lost and the effect of hormonal therapy is markedly reduced (reviewed in Reference [189]). The volume of the ischemic lesion in mice was reduced by the administration of the miRNA-148b inhibitor, leading to improved neurological functions [161]. Furthermore, recent research has demonstrated that extrinsic Wnt/ $\beta$-catenin pathway stimulation by synthetic ligands or chemical compounds performed immediately after ischemic stroke was capable of reducing the detrimental health consequences of the insult. The administration of Wnt3a directly to the neurogenic region of the brain promoted the proliferation of NS/PCs, which subsequently significantly reduced the extent of damage and improved the functional recovery of mice after MCAO [153]. A similar outcome was noted using intranasal administration of the Wnt3a ligand, whereas this effect was reversed by the co-administration of Wnt pathway-specific inhibitors, such as Dkk1 or tankyrase inhibitor XAV-939 [152]. It should be emphasized that these studies are still in their infancy, and most of the data were obtained using experimental rodent models. Importantly, the stimulation of the Wnt pathway could accompany the existing stroke treatment, and thus improve the patient's medical outcome. One recent study showed that administration of the Wnt pathway stimulator GSK3 $\beta$ inhibitor TWS119 reduced the risk of hemorrhagic transformation, a serious health complication upon treatment of ischemic patients with thrombolytic agent tPA [190]. Consistently, a number of studies have revealed the significant role of the $\mathrm{Wnt} / \beta$-catenin pathway in suppressing inflammation, inducing immune tolerance in dendritic cells, and also improving the BBB integrity (reviewed in Reference [191]). We conclude that the stimulation of the Wnt pathway after ischemic stroke could not only promote neurogenesis in the ischemic brain, but might also support other processes necessary for successful patient recovery.

\section{Future Perspectives}

Aberrant Wnt signaling underlies many types of human diseases, including cancer, and therefore a great effort has been made to identify the negative regulators of the signaling. On the other hand, a number of synthetic activators of the Wnt pathway were also (co)discovered (reviewed in Reference [192]). Since these activators might improve the recovery of patients after ischemic stroke, it is quite possible that the targeting of the Wnt pathway after ischemic stroke will enter clinics in the near future. However, one must always keep in mind that the Wnt signaling pathway's activity is not only essential for stem cell maintenance, but the pathway also promotes cell division, leading in some (extreme) situations to cellular transformation (reviewed in Reference [193]). This then raises the following questions: Is it safe to (hyper)stimulate the Wnt pathway? Does the risk of such treatment outweigh the benefits to the patient who suffered from ischemic stroke? We anticipate that, to answer these questions, a good understanding of the signaling pathways operating in the brain cells and tissue is essential. 
Although a large amount of experimental data has already been obtained, it is clear that further experiments will be needed to be able to fine-tune the signaling level of the Wnt signaling pathway. The results of these experiments should maximize the regeneration of the damaged brain, without any adverse effects on the patient's body.

Author Contributions: Writing—original draft preparation, T.K., L.J. and J.K.; writing—review and editing, V.K. and M.A.; visualization, L.J. All authors have read and agreed to the published version of the manuscript.

Funding: This work was funded by the Czech Science Foundation (grant numbers 19-03016S and 20-05770S) and by the Grant Agency of Charles University (grant number 330119). L.J. and V.K. were supported by the Academy of Sciences of the Czech Republic (RVO 68378050-KAV-NPUI). The Light Microscopy Core Facility of the Institute of Molecular Genetics of the ASCR, v.v.i. was supported by MEYS (LM2015062) and OPPK (CZ.2.16/3.1.00/21547).

Acknowledgments: We thank Sarka Takacova and Frances Zatrepalkova for critically reading the manuscript.

Conflicts of Interest: The authors declare no conflict of interest. The funders had no role in the writing of the manuscript.

\section{Abbreviations}

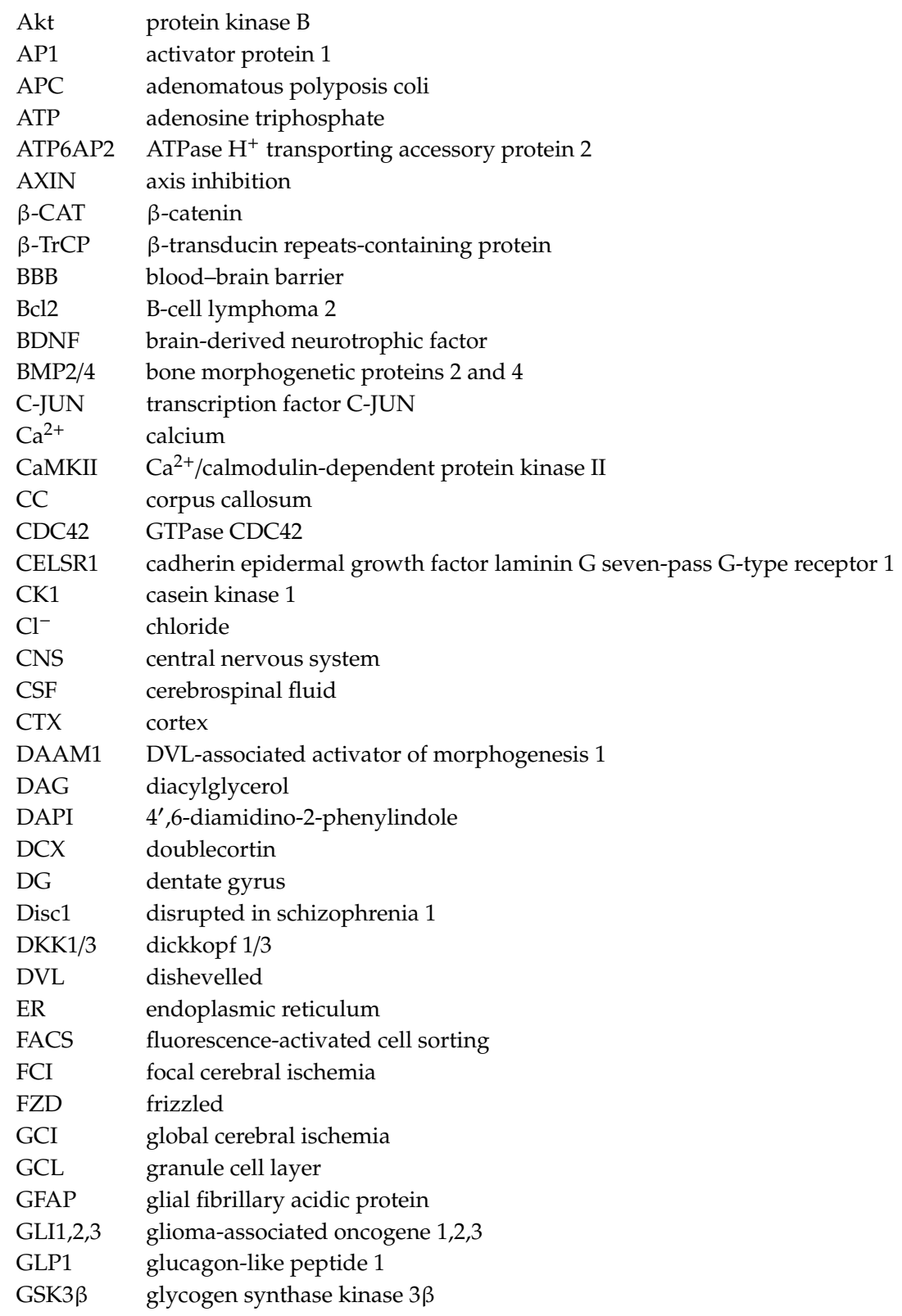


HIF1 $\alpha$ hypoxia-inducible factor $1 \alpha$

HIP hippocampus

Hipk1 homeodomain interacting protein kinase 1

IP3 inositol trisphosphate

iPSCs induced pluripotent stem cells

JNK c-Jun N-terminal kinase

LGR5 leucine-rich repeat-containing $G$ protein-coupled receptor 5

$\mathrm{LiCl}$ lithium chloride

LINE1 long interspersed nuclear elements 1

LRP5/6 low-density lipoprotein receptor-related protein 5/6

LVs lateral ventricles

MAPK mitogen-activated protein kinase

MBP myelin basic protein

MCAO middle cerebral artery occlusion

Meg3 maternally expressed gene 3

miRNA microRNA

MSCs mesenchymal stem cells

$\mathrm{Na}^{+} \quad$ sodium

NeuroD1 neurogenic differentiation 1

NFAT nuclear factor of activated T-cells

NG2 neuron-glial antigen 2

NLK nemo-like kinase

NPCs neural progenitor cells

NS/PCs neural stem/progenitor cells

NSCs neural stem cells

OPCs oligodendrocyte precursor cells

P phosphorylation

PCNA proliferating cell nuclear antigen

PCP planar cell polarity

PDGFR $\alpha$ platelet-derived growth factor receptor $\alpha$

PIP2 phosphatidylinositol 4,5-bisphosphate

PKC protein kinase $\mathrm{C}$

PLC phospholipase $\mathrm{C}$

Prox1 prospero-related homeodomain transcription factor 1

RAC1 Rac family small GTPase 1

RhoA Ras homolog family member A

ROCK Rho-associated kinase

ROR receptor tyrosine kinase ROR

ROS reactive oxygen species

RT-PCR reverse transcription polymerase chain reaction

RYK receptor tyrosine kinase RYK

sFRPs secreted FZD-related proteins

SGZ subgranular zone

Shh sonic hedgehog

siRNA small interfering RNA

Sox2 SRY-box transcription factor 2

STR striatum

SVZ subventricular zone

TCF/LEF T-cell factor/lymphoid enhancer-binding factor

TIMP1 tissue inhibitor of metalloproteinases 1

TLE transducin-like enhancer of split

tPA tissue plasminogen activator

$\mathrm{Ub}$ ubiquitination

VEGF vascular endothelial growth factor

VW ventricular wall

WIF Wnt inhibitory factor

Wip1 wild-type p53-induced phosphatase 1

WLS Wntless 


\section{References}

1. Hoseth, E.Z.; Krull, F.; Dieset, I.; Mørch, R.H.; Hope, S.; Gardsjord, E.S.; Steen, N.E.; Melle, I.; Brattbakk, H.R.; Steen, V.M.; et al. Exploring the Wnt signaling pathway in schizophrenia and bipolar disorder. Transl. Psychiatry 2018, 8. [CrossRef]

2. Tapia-Rojas, C.; Inestrosa, N. Loss of canonical Wnt signaling is involved in the pathogenesis of Alzheimer's disease. Neural Regen. Res. 2018, 13, 1705. [CrossRef]

3. L'Episcopo, F.; Tirolo, C.; Peruzzotti-Jametti, L.; Serapide, M.F.; Testa, N.; Caniglia, S.; Balzarotti, B.; Pluchino, S.; Marchetti, B. Neural stem cell grafts promote astroglia-driven neurorestoration in the aged parkinsonian brain via Wnt/ $\beta$-catenin signaling. Stem Cells 2018, 36, 1179-1197. [CrossRef]

4. Belov Kirdajova, D.; Kriska, J.; Tureckova, J.; Anderova, M. Ischemia-triggered glutamate excitotoxicity from the perspective of glial cells. Front. Cell. Neurosci. 2020, 14. [CrossRef] [PubMed]

5. Zhan, L.; Liu, D.; Wen, H.; Hu, J.; Pang, T.; Sun, W.; Xu, E. Hypoxic postconditioning activates the Wnt/ $\beta$-catenin pathway and protects against transient global cerebral ischemia through Dkk1 Inhibition and GSK-3 $\beta$ inactivation. FASEB J. 2019, 33, 9291-9307. [CrossRef] [PubMed]

6. Liu, B.; Tang, J.; Li, S.Y.; Zhang, Y.Q.; Li, Y.; Dong, X.L. Involvement of the Wnt signaling pathway and cell apoptosis in the rat hippocampus following cerebral ischemia/reperfusion injury. Neural Regen. Res. 2013, 8, 70-75. [CrossRef] [PubMed]

7. Kirdajova, D.; Anderova, M. NG2 cells and their neurogenic potential. Curr. Opin. Pharmacol. 2019, 50, 53-60. [CrossRef] [PubMed]

8. Valny, M.; Honsa, P.; Waloschkova, E.; Matuskova, H.; Kriska, J.; Kirdajova, D.; Androvic, P.; Valihrach, L.; Kubista, M.; Anderova, M. A single-cell analysis reveals multiple roles of oligodendroglial lineage cells during post-ischemic regeneration. Glia 2018, 66, 1068-1081. [CrossRef] [PubMed]

9. Bernstock, J.D.; Peruzzotti-Jametti, L.; Ye, D.; Gessler, F.A.; Maric, D.; Vicario, N.; Lee, Y.-J.; Pluchino, S.; Hallenbeck, J.M. Neural stem cell transplantation in ischemic stroke: A role for preconditioning and cellular engineering. J. Cereb. Blood Flow Metab. 2017, 37, 2314-2319. [CrossRef]

10. Varela-Nallar, L.; Inestrosa, N.C. Wnt signaling in the regulation of adult hippocampal neurogenesis. Front. Cell. Neurosci. 2013, 7. [CrossRef]

11. Chae, W.-J.; Bothwell, A.L.M. Canonical and non-canonical Wnt signaling in immune cells. Trends Immunol. 2018, 39, 830-847. [CrossRef] [PubMed]

12. Komekado, H.; Yamamoto, H.; Chiba, T.; Kikuchi, A. Glycosylation and palmitoylation of Wnt-3a are coupled to produce an active form of Wnt-3a. Genes Cells 2007, 12, 521-534. [CrossRef] [PubMed]

13. Bänziger, C.; Soldini, D.; Schütt, C.; Zipperlen, P.; Hausmann, G.; Basler, K. Wntless, a conserved membrane protein dedicated to the secretion of Wnt proteins from signaling cells. Cell 2006, 125, 509-522. [CrossRef] [PubMed]

14. De Herreros, A.G.; Duñach, M. Intracellular signals activated by canonical Wnt ligands independent of GSK3 inhibition and $\beta$-catenin stabilization. Cells 2019, 8, 1148. [CrossRef]

15. Van Amerongen, R. Alternative Wnt pathways and receptors. Cold Spring Harb. Perspect. Biol. $2012,4$. [CrossRef]

16. Katoh, M. Canonical and non-canonical Wnt signaling in cancer stem cells and their niches: Cellular heterogeneity, omics reprogramming, targeted therapy and tumor plasticity (Review). Int. J. Oncol. 2017, 51, 1357-1369. [CrossRef]

17. Hendrickx, G.; Boudin, E.; Verbeek, M.; Fransen, E.; Mortier, G.; Van Hul, W. Wnt16 requires G $\alpha$ subunits as intracellular partners for both its canonical and non-canonical WNT signalling activity in osteoblasts. Calcif. Tissue Int. 2020, 106, 294-302. [CrossRef] [PubMed]

18. Flores-Hernández, E.; Velázquez, D.M.; Castañeda-Patlán, M.C.; Fuentes-García, G.; Fonseca-Camarillo, G.; Yamamoto-Furusho, J.K.; Romero-Avila, M.T.; García-Sáinz, J.A.; Robles-Flores, M. Canonical and non-canonical Wnt signaling are simultaneously activated by Wnts in colon cancer cells. Cell. Signal. 2020, 72. [CrossRef]

19. Fan, J.; Wei, Q.; Liao, J.; Zou, Y.; Song, D.; Xiong, D.; Ma, C.; Hu, X.; Qu, X.; Chen, L.; et al. Noncanonical Wnt signaling plays an important role in modulating canonical Wnt-regulated stemness, proliferation and terminal differentiation of hepatic progenitors. Oncotarget 2017, 8, 27105-27119. [CrossRef] 
20. Brembeck, F.H.; Rosário, M.; Birchmeier, W. Balancing cell adhesion and Wnt signaling, the key role of $\beta$-catenin. Curr. Opin. Genet. Dev. 2006, 16, 51-59. [CrossRef]

21. Ladoux, B.; Nelson, W.J.; Yan, J.; Mège, R.M. The mechanotransduction machinery at work at adherens junctions. Integr. Biol. 2015, 7, 1109-1119. [CrossRef] [PubMed]

22. Dar, M.S.; Singh, P.; Singh, G.; Jamwal, G.; Hussain, S.S.; Rana, A.; Akhter, Y.; Monga, S.P.; Dar, M.J. Terminal regions of $\beta$-catenin are critical for regulating its adhesion and transcription functions. Biochim. Biophys. Acta-Mol. Cell Res. 2016, 1863, 2345-2357. [CrossRef]

23. Gao, J.; Liao, Y.; Qiu, M.; Shen, W. Wnt/ $\beta$-catenin signaling in neural stem cell homeostasis and neurological diseases. Neuroscientist 2020. [CrossRef]

24. Komiya, Y.; Habas, R. Wnt signal transduction pathways. Organogenesis 2008, 4, 68-75. [CrossRef]

25. Gao, C.; Chen, Y.-G. Dishevelled: The hub of Wnt signaling. Cell. Signal. 2010, 22, 717-727. [CrossRef] [PubMed]

26. Cselenyi, C.S.; Jernigan, K.K.; Tahinci, E.; Thorne, C.A.; Lee, L.A.; Lee, E. LRP6 transduces a canonical Wnt signal independently of Axin degradation by inhibiting GSK3's phosphorylation of $\beta$-catenin. Proc. Natl. Acad. Sci. USA 2008, 105, 8032-8037. [CrossRef]

27. Nusse, R.; Clevers, H. Wnt/ $\beta$-catenin signaling, disease, and emerging therapeutic modalities. Cell 2017, 169, 985-999. [CrossRef]

28. Krausova, M.; Korinek, V. Wnt signaling in adult intestinal stem cells and cancer. Cell. Signal. 2014, 26, 570-579. [CrossRef]

29. The Wnt Homepage. Available online: http://web.stanford.edu/group/nusselab/cgi-bin/wnt/ (accessed on 25 June 2020).

30. Bengoa-Vergniory, N.; Kypta, R.M. Canonical and noncanonical Wnt signaling in neural stem/progenitor cells. Cell. Mol. Life Sci. 2015, 72, 4157-4172. [CrossRef]

31. Sugimura, R.; Li, L. Noncanonical Wnt signaling in vertebrate development, stem cells, and diseases. Birth Defects Res. C Embryo Today 2010, 90, 243-256. [CrossRef]

32. Green, J.; Nusse, R.; Van Amerongen, R. The role of Ryk and Ror receptor tyrosine kinases in wnt signal transduction. Cold Spring Harb. Perspect. Biol. 2014, 6. [CrossRef] [PubMed]

33. Ameyar, M.; Wisniewska, M.; Weitzman, J.B. A role for AP-1 in apoptosis: The case for and against. Biochimie 2003, 85, 747-752. [CrossRef] [PubMed]

34. Schlessinger, K.; McManus, E.J.; Hall, A. Cdc42 and noncanonical Wnt signal transduction pathways cooperate to promote cell polarity. J. Cell Biol. 2007, 178, 355-361. [CrossRef]

35. Ishitani, T.; Kishida, S.; Hyodo-Miura, J.; Ueno, N.; Yasuda, J.; Waterman, M.; Shibuya, H.; Moon, R.T.; Ninomiya-Tsuji, J.; Matsumoto, K. The TAK1-NLK mitogen-activated protein kinase cascade functions in the Wnt-5a/Ca2+ pathway to antagonize Wnt/ $\beta$-catenin signaling. Mol. Cell. Biol. 2003, 23, 131-139. [CrossRef]

36. MacDonald, B.T.; Tamai, K.; He, X. Wnt/beta-catenin signaling: Components, mechanisms, and diseases. Dev. Cell 2009, 17, 9-26. [CrossRef] [PubMed]

37. Mao, B.; Wu, W.; Davidson, G.; Marhold, J.; Li, M.; Mechler, B.M.; Dellus, H.; Hoppe, D.; Stannek, P.; Walter, C.; et al. Kremen proteins are Dickkopf receptors that regulate $W n t / \beta$-catenin signalling. Nature 2002, 417, 664-667. [CrossRef]

38. Okerlund, N.D.; Cheyette, B.N.R. Synaptic Wnt signaling-A contributor to major psychiatric disorders? J. Neurodev. Disord. 2011, 3, 162-174. [CrossRef]

39. Cselenyi, C.S.; Lee, E. Context-dependent activation or inhibition of Wnt-beta-Catenin signaling by kremen. Sci. Signal. 2008, 1, pe10. [CrossRef]

40. Faigle, R.; Song, H. Signaling mechanisms regulating adult neural stem cells and neurogenesis. Biochim. Biophys. Acta 2013, 1830, 2435-2448. [CrossRef]

41. Prajerova, I.; Honsa, P.; Chvatal, A.; Anderova, M. Distinct effects of sonic hedgehog and Wnt-7a on differentiation of neonatal neural stem/progenitor cells in vitro. Neuroscience 2010, 171, 693-711. [CrossRef]

42. Li, X.J.; Zhang, X.; Johnson, M.A.; Wang, Z.B.; LaVaute, T.; Zhang, S.C. Coordination of sonic hedgehog and Wnt signaling determines ventral and dorsal telencephalic neuron types from human embryonic stem cells. Development 2009, 136, 4055-4063. [CrossRef] [PubMed]

43. Carballo, G.B.; Honorato, J.R.; De Lopes, G.P.F.; De Sampaio E Spohr, T.C.L. A highlight on Sonic hedgehog pathway. Cell Commun. Signal. 2018, 16, 11. [CrossRef] [PubMed] 
44. Knoth, R.; Singec, I.; Ditter, M.; Pantazis, G.; Capetian, P.; Meyer, R.P.; Horvat, V.; Volk, B.; Kempermann, G. Murine features of neurogenesis in the human hippocampus across the lifespan from 0 to 100 years. PLOS ONE 2010, 5, e8809. [CrossRef] [PubMed]

45. Wang, C.; Liu, F.; Liu, Y.Y.; Zhao, C.H.; You, Y.; Wang, L.; Zhang, J.; Wei, B.; Ma, T.; Zhang, Q.; et al. Identification and characterization of neuroblasts in the subventricular zone and rostral migratory stream of the adult human brain. Cell Res. 2011, 21, 1534-1550. [CrossRef]

46. Boldrini, M.; Fulmore, C.A.; Tartt, A.N.; Simeon, L.R.; Pavlova, I.; Poposka, V.; Rosoklija, G.B.; Stankov, A.; Arango, V.; Dwork, A.J.; et al. Human hippocampal neurogenesis persists throughout aging. Cell Stem Cell 2018, 22, 589-599. [CrossRef]

47. Sorrells, S.F.; Paredes, M.F.; Cebrian-Silla, A.; Sandoval, K.; Qi, D.; Kelley, K.W.; James, D.; Mayer, S.; Chang, J.; Auguste, K.I.; et al. Human hippocampal neurogenesis drops sharply in children to undetectable levels in adults. Nature 2018, 555, 377-381. [CrossRef]

48. Mizrak, D.; Levitin, H.M.; Delgado, A.C.; Crotet, V.; Yuan, J.; Chaker, Z.; Silva-Vargas, V.; Sims, P.A.; Doetsch, F. Single-cell analysis of regional differences in adult V-SVZ neural stem cell lineages. Cell Rep. 2019, 26, 394-406. [CrossRef]

49. Shin, J.; Berg, D.A.; Zhu, Y.; Shin, J.Y.; Song, J.; Bonaguidi, M.A.; Enikolopov, G.; Nauen, D.W.; Christian, K.M.; Ming, G.L.; et al. Single-cell RNA-seq with waterfall reveals molecular cascades underlying adult neurogenesis. Cell Stem Cell 2015, 17, 360-372. [CrossRef]

50. Urbán, N.; Guillemot, F. Neurogenesis in the embryonic and adult brain: Same regulators, different roles. Front. Cell. Neurosci. 2014, 8. [CrossRef]

51. Kuwabara, T.; Hsieh, J.; Muotri, A.; Yeo, G.; Warashina, M.; Lie, D.C.; Moore, L.; Nakashima, K.; Asashima, M.; Gage, F.H. Wnt-mediated activation of NeuroD1 and retro-elements during adult neurogenesis. Nat. Neurosci. 2009, 12, 1097-1105. [CrossRef]

52. Lie, D.C.; Colamarino, S.A.; Song, H.J.; Désiré, L.; Mira, H.; Consiglio, A.; Lein, E.S.; Jessberger, S.; Lansford, H.; Dearie, A.R.; et al. Wnt signalling regulates adult hippocampal neurogenesis. Nature 2005, 437, 1370-1375. [CrossRef]

53. Wexler, E.M.; Paucer, A.; Kornblum, H.I.; Plamer, T.D.; Geschwind, D.H. Endogenous Wnt signaling maintains neural progenitor cell potency. Stem Cells 2009, 27, 1130-1141. [CrossRef]

54. Qu, Q.; Sun, G.; Li, W.; Yang, S.; Ye, P.; Zhao, C.; Yu, R.T.; Gage, F.H.; Evans, R.M.; Shi, Y. Orphan nuclear receptor TLX activates Wnt/B-catenin signalling to stimulate neural stem cell proliferation and self-renewal. Nat. Cell Biol. 2010, 12, 31-40. [CrossRef]

55. Adachi, K.; Mirzadeh, Z.; Sakaguchi, M.; Yamashita, T.; Nikolcheva, T.; Gotoh, Y.; Peltz, G.; Gong, L.; Kawase, T.; Alvarez-Buylla, A.; et al. $\beta$-catenin signaling promotes proliferation of progenitor cells in the adult mouse subventricular zone. Stem Cells 2007, 25, 2827-2836. [CrossRef] [PubMed]

56. Mao, Y.; Ge, X.; Frank, C.L.; Madison, J.M.; Koehler, A.N.; Doud, M.K.; Tassa, C.; Berry, E.M.; Soda, T.; Singh, K.K.; et al. Disrupted in schizophrenia 1 regulates neuronal progenitor proliferation via modulation of GSK3 $\beta / \beta$-catenin signaling. Cell 2009, 136, 1017-1031. [CrossRef]

57. Qu, Q.; Sun, G.; Murai, K.; Ye, P.; Li, W.; Asuelime, G.; Cheung, Y.-T.; Shi, Y. Wnt7a regulates multiple steps of neurogenesis. Mol. Cell. Biol. 2013, 33, 2551-2559. [CrossRef] [PubMed]

58. Karalay, Ö.; Doberauer, K.; Vadodaria, K.C.; Knobloch, M.; Berti, L.; Miquelajauregui, A.; Schwark, M.; Jagasia, R.; Taketo, M.M.; Tarabykin, V.; et al. Prospero-related homeobox 1 gene (Prox1) is regulated by canonical Wnt signaling and has a stage-specific role in adult hippocampal neurogenesis. Proc. Natl. Acad. Sci. USA 2011, 108, 5807-5812. [CrossRef]

59. Marinaro, C.; Pannese, M.; Weinandy, F.; Sessa, A.; Bergamaschi, A.; Taketo, M.M.; Broccoli, V.; Comi, G.; Götz, M.; Martino, G.; et al. Wnt signaling has opposing roles in the developing and the adult brain that are modulated by Hipk1. Cereb. Cortex 2012, 22, 2415-2427. [CrossRef]

60. Okamoto, M.; Inoue, K.; Iwamura, H.; Terashima, K.; Soya, H.; Asashima, M.; Kuwabara, T. Reduction in paracrine Wnt3 factors during aging causes impaired adult neurogenesis. FASEB J. 2011, 25, 3570-3582. [CrossRef]

61. Solberg, N.; Machon, O.; Krauss, S. Effect of canonical Wnt inhibition in the neurogenic cortex, hippocampus, and premigratory dentate gyrus progenitor pool. Dev. Dyn. 2008, 237, 1799-1811. [CrossRef] 
62. Jang, M.-H.; Bonaguidi, M.A.; Kitabatake, Y.; Sun, J.; Song, J.; Kang, E.; Jun, H.; Zhong, C.; Su, Y.; Guo, J.U.; et al. Secreted frizzled-related protein 3 regulates activity-dependent adult hippocampal neurogenesis. Cell Stem Cell 2013, 12, 215-223. [CrossRef]

63. Zhu, Y.; Demidov, O.N.; Goh, A.M.; Virshup, D.M.; Lane, D.P.; Bulavin, D.V. Phosphatase WIP1 regulates adult neurogenesis and WNT signaling during aging. J. Clin. Investig. 2014, 124, 3263-3273. [CrossRef]

64. Seib, D.R.M.; Corsini, N.S.; Ellwanger, K.; Plaas, C.; Mateos, A.; Pitzer, C.; Niehrs, C.; Celikel, T.; Martin-Villalba, A. Loss of Dickkopf-1 restores neurogenesis in old age and counteracts cognitive decline. Cell Stem Cell 2013, 12, 204-214. [CrossRef]

65. Marzo, A.; Galli, S.; Lopes, D.; McLeod, F.; Podpolny, M.; Segovia-Roldan, M.; Ciani, L.; Purro, S.; Cacucci, F.; Gibb, A.; et al. Reversal of synapse degeneration by restoring Wnt signaling in the adult hippocampus. Curr. Biol. 2016, 26, 2551-2561. [CrossRef]

66. Kase, Y.; Otsu, K.; Shimazaki, T.; Okano, H. Involvement of p38 in age-related decline in adult neurogenesis via modulation of Wnt signaling. Stem Cell Rep. 2019, 12, 1313-1328. [CrossRef]

67. Bevilaqua, L.R.M.; Kerr, D.S.; Medina, J.H.; Izquierdo, I.; Cammarota, M. Inhibition of hippocampal Jun $\mathrm{N}$-terminal kinase enhances short-term memory but blocks long-term memory formation and retrieval of an inhibitory avoidance task. Eur. J. Neurosci. 2003, 17, 897-902. [CrossRef]

68. Reinecke, K.; Herdegen, T.; Eminel, S.; Aldenhoff, J.B.; Schiffelholz, T. Knockout of c-Jun N-terminal kinases 1, 2 or 3 isoforms induces behavioural changes. Behav. Brain Res. 2013, 245, 88-95. [CrossRef] [PubMed]

69. Farías, G.G.; Alfaro, I.E.; Cerpa, W.; Grabowski, C.P.; Godoy, J.A.; Bonansco, C.; Inestrosa, N.C. Wnt-5a/JNK signaling promotes the clustering of PSD-95 in hippocampal neurons. J. Biol. Chem. 2009, 284, 15857-15866. [CrossRef] [PubMed]

70. Varela-Nallar, L.; Alfaro, I.E.; Serrano, F.G.; Parodi, J.; Inestrosa, N.C. Wingless-type family member 5A (Wnt-5a) stimulates synaptic differentiation and function of glutamatergic synapses. Proc. Natl. Acad. Sci. USA 2010, 107, 21164-21169. [CrossRef]

71. Slater, P.G.; Ramirez, V.T.; Gonzalez-Billault, C.; Varela-Nallar, L.; Inestrosa, N.C. Frizzled-5 receptor is involved in neuronal polarity and morphogenesis of hippocampal neurons. PLoS ONE 2013, 8, e78892. [CrossRef] [PubMed]

72. Raivich, G.; Bohatschek, M.; Da Costa, C.; Iwata, O.; Galiano, M.; Hristova, M.; Nateri, A.S.; Makwana, M.; Riera-Sans, L.; Wolfer, D.P.; et al. The AP-1 transcription factor c-Jun is required for efficient axonal regeneration. Neuron 2004, 43, 57-67. [CrossRef] [PubMed]

73. Bengoa-Vergniory, N.; Gorroño-Etxebarria, I.; González-Salazar, I.; Kypta, R.M. A switch from canonical to noncanonical wnt signaling mediates early differentiation of human neural stem cells. Stem Cells 2014, 32, 3196-3208. [CrossRef] [PubMed]

74. Arredondo, S.B.; Guerrero, F.G.; Herrera-Soto, A.; Jensen-Flores, J.; Bustamante, D.B.; Oñate-Ponce, A.; Henny, P.; Varas-Godoy, M.; Inestrosa, N.C.; Varela-Nallar, L. Wnt5a promotes differentiation and development of adult-born neurons in the hippocampus by noncanonical Wnt signaling. Stem Cells 2020, 38, 422-436. [CrossRef] [PubMed]

75. Yu, J.M.; Kim, J.H.; Song, G.S.; Jung, J.S. Increase in proliferation and differentiation of neural progenitor cells isolated from postnatal and adult mice brain by Wnt-3a and Wnt-5a. Mol. Cell. Biochem. 2006, 288, 17-28. [CrossRef] [PubMed]

76. Schafer, S.T.; Han, J.; Pena, M.; Von Bohlen und Halbach, O.; Peters, J.; Gage, F.H. The Wnt adaptor protein ATP6AP2 regulates multiple stages of adult hippocampal neurogenesis. J. Neurosci. 2015, 35, 4983-4998. [CrossRef] [PubMed]

77. Chavali, M.; Klingener, M.; Kokkosis, A.G.; Garkun, Y.; Felong, S.; Maffei, A.; Aguirre, A. Non-canonical Wnt signaling regulates neural stem cell quiescence during homeostasis and after demyelination. Nat. Commun. 2018, 9. [CrossRef]

78. Clevers, H.; Loh, K.M.; Nusse, R. An integral program for tissue renewal and regeneration: Wnt signaling and stem cell control. Science 2014, 346, 1248012. [CrossRef]

79. Herculano-Houzel, S. The glia/neuron ratio: How it varies uniformly across brain structures and species and what that means for brain physiology and evolution. Glia 2014, 62, 1377-1391. [CrossRef]

80. Jäkel, S.; Dimou, L. Glial cells and their function in the adult brain: A journey through the history of their ablation. Front. Cell. Neurosci. 2017, 11,1-17. [CrossRef] 
81. Cui, W.; Allen, N.D.; Skynner, M.; Gusterson, B.; Clark, A.J. Inducible ablation of astrocytes shows that these cells are required for neuronal survival in the adult brain. Glia 2001, 34, 272-282. [CrossRef]

82. Schreiner, B.; Romanelli, E.; Liberski, P.; Ingold-Heppner, B.; Sobottka-Brillout, B.; Hartwig, T.; Chandrasekar, V.; Johannssen, H.; Zeilhofer, H.U.; Aguzzi, A.; et al. Astrocyte depletion impairs redox homeostasis and triggers neuronal loss in the adult CNS. Cell Rep. 2015, 12, 1377-1384. [CrossRef] [PubMed]

83. Liu, X.; Bolteus, A.J.; Balkin, D.M.; Henschel, O.; Bordey, A. GFAP-expressing cells in the postnatal subventricular zone display a unique glial phenotype intermediate between radial glia and astrocytes. Glia 2006, 54, 394-410. [CrossRef] [PubMed]

84. Armenteros, T.; Andreu, Z.; Hortigüela, R.; Lie, D.C.; Mira, H. BMP and WNT signalling cooperate through LEF1 in the neuronal specification of adult hippocampal neural stem and progenitor cells. Sci. Rep. 2018, 8, 9241. [CrossRef]

85. Moreno-Estellés, M.; González-Gómez, P.; Hortigüela, R.; Díaz-Moreno, M.; San Emeterio, J.; Carvalho, A.L.; Fariñas, I.; Mira, H. Symmetric expansion of neural stem cells from the adult olfactory bulb is driven by astrocytes via WNT7A. Stem Cells 2012, 30, 2796-2809. [CrossRef] [PubMed]

86. Falk, S.; Götz, M. Glial control of neurogenesis. Curr. Opin. Neurobiol. 2017, 47, 188-195. [CrossRef] [PubMed]

87. ffrench-Constant, C.; Raff, M.C. Proliferating bipotential glial progenitor cells in adult rat optic nerve. Nature 1986, 319, 499-502. [CrossRef]

88. Hughes, E.G.; Kang, S.H.; Fukaya, M.; Bergles, D.E. Oligodendrocyte progenitors balance growth with self-repulsion to achieve homeostasis in the adult brain. Nat. Neurosci. 2013, 16, 668-676. [CrossRef]

89. Robins, S.C.; Villemain, A.; Liu, X.; Djogo, T.; Kryzskaya, D.; Storch, K.F.; Kokoeva, M.V. Extensive regenerative plasticity among adult NG2-glia populations is exclusively based on self-renewal. Glia 2013, 61, 1735-1747. [CrossRef]

90. Birey, F.; Aguirre, A. Age-dependent netrin-1 signaling regulates NG2+ glial cell spatial homeostasis in normal adult gray matter. J. Neurosci. 2015, 35, 6946-6951. [CrossRef]

91. Chari, D.M.; Crang, A.J.; Blakemore, W.F. Decline in rate of colonization of oligodendrocyte progenitor cell (OPC)-depleted tissue by adult OPCs with age. J. Neuropathol. Exp. Neurol. 2003, 62, 908-916. [CrossRef]

92. Schneider, S.; Gruart, A.; Grade, S.; Zhang, Y.; Kröger, S.; Kirchhoff, F.; Eichele, G.; Delgado García, J.M.; Dimou, L. Decrease in newly generated oligodendrocytes leads to motor dysfunctions and changed myelin structures that can be rescued by transplanted cells. Glia 2016, 64, 2201-2218. [CrossRef] [PubMed]

93. Birey, F.; Kloc, M.; Chavali, M.; Hussein, I.; Wilson, M.; Christoffel, D.J.; Chen, T.; Frohman, M.A.; Robinson, J.K.; Russo, S.J.; et al. Genetic and stress-induced loss of NG2 glia triggers emergence of depressive-like behaviors through reduced secretion of FGF2. Neuron 2015, 88, 941-956. [CrossRef]

94. Belachew, S.; Chittajallu, R.; Aguirre, A.A.; Yuan, X.; Kirby, M.; Anderson, S.; Gallo, V. Postnatal NG2 proteoglycan-expressing progenitor cells are intrinsically multipotent and generate functional neurons. J. Cell Biol. 2003, 161, 169-186. [CrossRef] [PubMed]

95. Kondo, T.; Raff, M. Oligodendrocyte precursor cells reprogrammed to become multipotential CNS stem cells. Science 2000, 289, 1754-1757. [CrossRef]

96. Kang, S.H.; Fukaya, M.; Yang, J.K.; Rothstein, J.D.; Bergles, D.E. NG2+ CNS glial progenitors remain committed to the oligodendrocyte lineage in postnatal life and following neurodegeneration. Neuron 2010, 68, 668-681. [CrossRef]

97. Rivers, L.E.; Young, K.M.; Rizzi, M.; Jamen, F.; Psachoulia, K.; Wade, A.; Kessaris, N.; Richardson, W.D. PDGFRA/NG2 glia generate myelinating oligodendrocytes and piriform projection neurons in adult mice. Nat. Neurosci. 2008, 11, 1392-1401. [CrossRef] [PubMed]

98. Zhu, X.; Hill, R.A.; Dietrich, D.; Komitova, M.; Suzuki, R.; Nishiyama, A. Age-dependent fate and lineage restriction of single NG2 cells. Development 2011, 138, 745-753. [CrossRef]

99. Heinrich, C.; Bergami, M.; Gascón, S.; Lepier, A.; Viganò, F.; Dimou, L.; Sutor, B.; Berninger, B.; Götz, M. Sox2-mediated conversion of NG2 glia into induced neurons in the injured adult cerebral cortex. Stem Cell Rep. 2014, 3, 1000-1014. [CrossRef]

100. Honsa, P.; Pivonkova, H.; Dzamba, D.; Filipova, M.; Anderova, M. Polydendrocytes display large lineage plasticity following focal cerebral ischemia. PLoS ONE 2012, 7, e36816. [CrossRef]

101. Honsa, P.; Valny, M.; Kriska, J.; Matuskova, H.; Harantova, L.; Kirdajova, D.; Valihrach, L.; Androvic, P.; Kubista, M.; Anderova, M. Generation of reactive astrocytes from NG2 cells is regulated by sonic hedgehog. Glia 2016, 64, 1518-1531. [CrossRef] 
102. Tatsumi, K.; Takebayashi, H.; Manabe, T.; Tanaka, K.F.; Makinodan, M.; Yamauchi, T.; Makinodan, E.; Matsuyoshi, H.; Okuda, H.; Ikenaka, K.; et al. Genetic fate mapping of Olig2 progenitors in the injured adult cerebral cortex reveals preferential differentiation into astrocytes. J. Neurosci. Res. 2008, 86, 3494-3502. [CrossRef] [PubMed]

103. Xiao, L.; Ohayon, D.; Mckenzie, I.A.; Sinclair-Wilson, A.; Wright, J.L.; Fudge, A.D.; Emery, B.; Li, H.; Richardson, W.D. Rapid production of new oligodendrocytes is required in the earliest stages of motor-skill learning. Nat. Neurosci. 2016, 19, 1210-1217. [CrossRef] [PubMed]

104. Chew, L.J.; Shen, W.; Ming, X.; Senatorov, V.V.; Chen, H.L.; Cheng, Y.; Hong, E.; Knoblach, S.; Gallo, V. SRY-Box containing gene 17 regulates the $\mathrm{Wnt} / \beta$-catenin signaling pathway in oligodendrocyte progenitor cells. J. Neurosci. 2011, 31, 13921-13935. [CrossRef] [PubMed]

105. Hill, R.A.; Patel, K.D.; Medved, J.; Reiss, A.M.; Nishiyama, A. NG2 cells in white matter but not gray matter proliferate in response to PDGF. J. Neurosci. 2013, 33, 14558-14566. [CrossRef]

106. Dai, Z.-M.; Sun, S.; Wang, C.; Huang, H.; Hu, X.; Zhang, Z.; Lu, Q.R.; Qiu, M. Stage-specific regulation of oligodendrocyte development by Wnt/ $\beta$-catenin signaling. J. Neurosci. 2014, 34, 8467-8473. [CrossRef]

107. Ye, F.; Chen, Y.; Hoang, T.; Montgomery, R.L.; Zhao, X.; Bu, H.; Hu, T.; Taketo, M.M.; Van Es, J.H.; Clevers, H.; et al. HDAC1 and HDAC2 regulate oligodendrocyte differentiation by disrupting the beta-catenin-TCF interaction. Nat. Neurosci. 2009, 12, 829-838. [CrossRef]

108. Feigenson, K.; Reid, M.; See, J.; Crenshaw, E.B.; Grinspan, J.B. Wnt signaling is sufficient to perturb oligodendrocyte maturation. Mol. Cell. Neurosci. 2009, 42, 255-265. [CrossRef]

109. Feigenson, K.; Reid, M.; See, J.; Crenshaw, E.B., III; Grinspan, J.B. Canonical Wnt signalling requires the BMP pathway to inhibit oligodendrocyte maturation. ASN Neuro 2011, 3, e00061. [CrossRef]

110. Lang, J.; Maeda, Y.; Bannerman, P.; Xu, J.; Horiuchi, M.; Pleasure, D.; Guo, F. Adenomatous polyposis coli regulates oligodendroglial development. J. Neurosci. 2013, 33, 3113-3130. [CrossRef] [PubMed]

111. Ortega, F.; Gascón, S.; Masserdotti, G.; Deshpande, A.; Simon, C.; Fischer, J.; Dimou, L.; Lie, D.C.; Schroeder, T.; Berninger, B. Oligodendrogliogenic and neurogenic adult subependymal zone neural stem cells constitute distinct lineages and exhibit differential responsiveness to Wnt signalling. Nat. Cell Biol. 2013, 15, 602-613. [CrossRef]

112. Azim, K.; Butt, A.M. GSK3 $\beta$ negatively regulates oligodendrocyte differentiation and myelination in vivo. Glia 2011, 59, 540-553. [CrossRef] [PubMed]

113. Meffre, D.; Massaad, C.; Grenier, J. Lithium chloride stimulates plp and mbp expression in oligodendrocytes via wnt/ $\beta$-catenin and akt/creb pathways. Neuroscience 2015, 284, 962-971. [CrossRef] [PubMed]

114. Bowman, A.N.; Van Amerongen, R.; Palmer, T.D.; Nusse, R. Lineage tracing with Axin2 reveals distinct developmental and adult populations of $\mathrm{Wnt} / \beta$-catenin-responsive neural stem cells. Proc. Natl. Acad. Sci. USA 2013, 110, 7324-7329. [CrossRef] [PubMed]

115. Lie, D.C.; Dziewczapolski, G.; Willhoite, A.R.; Kaspar, B.K.; Shults, C.W.; Gage, F.H. The adult substantia nigra contains progenitor cells with neurogenic potential. J. Neurosci. 2002, 22, 6639-6649. [CrossRef]

116. Shihabuddin, L.S.; Horner, P.J.; Ray, J.; Gage, F.H. Adult spinal cord stem cells generate neurons after transplantation in the adult dentate gyrus. J. Neurosci. 2000, 20, 8727-8735. [CrossRef] [PubMed]

117. Suhonen, J.O.; Peterson, D.A.; Ray, J.; Gage, F.H. Differentiation of adult hippocampus-derived progenitors into olfactory neurons in vivo. Nature 1996, 383, 624-627. [CrossRef]

118. Llorens-Bobadilla, E.; Martin-Villalba, A. Adult NSC diversity and plasticity: The role of the niche. Curr. Opin. Neurobiol. 2017, 42, 68-74. [CrossRef]

119. Kriska, J.; Honsa, P.; Dzamba, D.; Butenko, O.; Kolenicova, D.; Janeckova, L.; Nahacka, Z.; Andera, L.; Kozmik, Z.; Taketo, M.M.; et al. Manipulating Wnt signaling at different subcellular levels affects the fate of neonatal neural stem/progenitor cells. Brain Res. 2016, 1651, 73-87. [CrossRef]

120. Sun, S.; Zhu, X.J.; Huang, H.; Guo, W.; Tang, T.; Xie, B.; Xu, X.; Zhang, Z.; Shen, Y.; Dai, Z.M.; et al. Wnt signaling represses astrogliogenesis via Ngn2-dependent direct suppression of astrocyte gene expression. Glia 2019, 67, 1333-1343. [CrossRef]

121. Azim, K.; Akkermann, R.; Cantone, M.; Vera, J.; Jadasz, J.J.; Küry, P. Transcriptional profiling of ligand expression in cell specific populations of the adult mouse forebrain that regulates neurogenesis. Front. Neurosci. 2018, 12. [CrossRef] 
122. Corada, M.; Orsenigo, F.; Bhat, G.P.; Conze, L.L.; Breviario, F.; Cunha, S.I.; Claesson-Welsh, L.; Beznoussenko, G.V.; Mironov, A.A.; Bacigaluppi, M.; et al. Fine-tuning of Sox17 and canonical Wnt coordinates the permeability properties of the blood-brain barrier. Circ. Res. 2019, 124, 511-525. [CrossRef] [PubMed]

123. Laksitorini, M.D.; Yathindranath, V.; Xiong, W.; Hombach-Klonisch, S.; Miller, D.W. Modulation of $\mathrm{Wnt} / \beta$-catenin signaling promotes blood-brain barrier phenotype in cultured brain endothelial cells. Sci. Rep. 2019, 9. [CrossRef] [PubMed]

124. Mirzadeh, Z.; Merkle, F.T.; Soriano-Navarro, M.; Garcia-Verdugo, J.M.; Alvarez-Buylla, A. Neural stem cells confer unique pinwheel architecture to the ventricular surface in neurogenic regions of the adult brain. Cell Stem Cell 2008, 3, 265-278. [CrossRef] [PubMed]

125. Paez-Gonzalez, P.; Abdi, K.; Luciano, D.; Liu, Y.; Soriano-Navarro, M.; Rawlins, E.; Bennett, V.; Garcia-Verdugo, J.M.; Kuo, C.T. Ank3-dependent SVZ niche assembly is required for the continued production of new neurons. Neuron 2011, 71, 61-75. [CrossRef]

126. Gonzalez-Fernandez, C.; Arevalo-Martin, A.; Paniagua-Torija, B.; Ferrer, I.; Rodriguez, F.J.; Garcia-Ovejero, D. Wnts are expressed in the ependymal region of the adult spinal cord. Mol. Neurobiol. 2017, 54, 6342-6355. [CrossRef]

127. Xing, L.; Anbarchian, T.; Tsai, J.M.; Plant, G.W.; Nusse, R. Wnt/ $\beta$-catenin signaling regulates ependymal cell development and adult homeostasis. Proc. Natl. Acad. Sci. USA 2018, 115, E5954-E5962. [CrossRef]

128. Ohata, S.; Nakatani, J.; Herranz-Pérez, V.; Cheng, J.G.; Belinson, H.; Inubushi, T.; Snider, W.D.; García-Verdugo, J.M.; Wynshaw-Boris, A.; Álvarez-Buylla, A. Loss of dishevelleds disrupts planar polarity in ependymal motile cilia and results in hydrocephalus. Neuron 2014, 83, 558-571. [CrossRef]

129. Sawamoto, K.; Wichterle, H.; Gonzalez-Perez, O.; Cholfin, J.A.; Yamada, M.; Spassky, N.; Murcia, N.S.; Garcia-Verdugo, J.M.; Marin, O.; Rubenstein, J.L.R.; et al. New neurons follow the flow of cerebrospinal fluid in the adult brain. Science 2006, 311, 629-632. [CrossRef]

130. Donnan, G.A.; Fisher, M.; Macleod, M.; Davis, S.M. Stroke. Lancet 2008, 371, 1612-1623. [CrossRef]

131. Woodruff, T.M.; Thundyil, J.; Tang, S.-C.; Sobey, C.G.; Taylor, S.M.; Arumugam, T.V. Pathophysiology, treatment, and animal and cellular models of human ischemic stroke. Mol. Neurodegener. 2011, 6, 11. [CrossRef]

132. Koh, S.H.; Park, H.H. Neurogenesis in stroke recovery. Transl. Stroke Res. 2017, 8, 3-13. [CrossRef] [PubMed]

133. Rossi, D.J.; Brady, J.D.; Mohr, C. Astrocyte metabolism and signaling during brain ischemia. Nat. Neurosci. 2007, 10, 1377-1386. [CrossRef] [PubMed]

134. Dirnagl, U.; Iadecola, C.; Moskowitz, M.A. Pathobiology of ischaemic stroke: An integrated view. Trends Neurosci. 1999, 22, 391-397. [CrossRef]

135. Rebai, O.; Amri, M. Chlorogenic acid prevents AMPA-mediated excitotoxicity in optic nerve oligodendrocytes through a PKC and caspase-dependent pathways. Neurotox. Res. 2018, 34, 559-573. [CrossRef] [PubMed]

136. Andrabi, S.S.; Parvez, S.; Tabassum, H. Ischemic stroke and mitochondria: Mechanisms and targets. Protoplasma 2020, 257, 335-343. [CrossRef]

137. Gelderblom, M.; Leypoldt, F.; Steinbach, K.; Behrens, D.; Choe, C.-U.; Siler, D.A.; Arumugam, T.V.; Orthey, E.; Gerloff, C.; Tolosa, E.; et al. Temporal and spatial dynamics of cerebral immune cell accumulation in stroke. Stroke 2009, 40, 1849-1857. [CrossRef]

138. Del Zoppo, G.J.; Hallenbeck, J.M. Advances in the vascular pathophysiology of ischemic stroke. Thromb. Res. 2000, 98, 73-81. [CrossRef]

139. Adams, K.L.; Gallo, V. The diversity and disparity of the glial scar. Nat. Neurosci. 2018, 21, 9-15. [CrossRef]

140. Huang, L.; Wu, Z.-B.; Zhuge, Q.; Zheng, W.; Shao, B.; Wang, B.; Sun, F.; Jin, K. Glial scar formation occurs in the human brain after ischemic stroke. Int. J. Med. Sci. 2014, 11, 344-348. [CrossRef]

141. Jansen, O.; Rohr, A. Neurothrombectomy in the treatment of acute ischaemic stroke. Nat. Rev. Neurol. 2013, 9, 645-652. [CrossRef]

142. Stenman, J.M.; Rajagopal, J.; Carroll, T.J.; Ishibashi, M.; McMahon, J.; McMahon, A.P. Canonical Wnt signaling regulates organ-specific assembly and differentiation of CNS vasculature. Science 2008, 322, 1247-1250. [CrossRef] [PubMed]

143. Liebner, S.; Corada, M.; Bangsow, T.; Babbage, J.; Taddei, A.; Czupalla, C.J.; Reis, M.; Felici, A.; Wolburg, H.; Fruttiger, M.; et al. Wnt/ $\beta$-catenin signaling controls development of the blood-brain barrier. J. Cell Biol. 2008, 183, 409-417. [CrossRef] [PubMed] 
144. Miao, Y.; Wang, R.; Wu, H.; Yang, S.; Qiu, Y. CPCGI confers neuroprotection by enhancing blood circulation and neurological function in cerebral ischemia/reperfusion rats. Mol. Med. Rep. 2019, 20, 2365-2372. [CrossRef] [PubMed]

145. Cappuccio, I. Induction of Dickkopf-1, a negative modulator of the Wnt pathway, is required for the development of ischemic neuronal death. J. Neurosci. 2005, 25, 2647-2657. [CrossRef] [PubMed]

146. Mastroiacovo, F.; Busceti, C.L.; Biagioni, F.; Moyanova, S.G.; Meisler, M.H.; Battaglia, G.; Caricasole, A.; Bruno, V.; Nicoletti, F. Induction of the Wnt antagonist, Dickkopf-1, contributes to the development of neuronal death in models of brain focal ischemia. J. Cereb. Blood Flow Metab. 2009, 29, 264-276. [CrossRef] [PubMed]

147. Li, Q.; Dashwood, W.M.; Zhong, X.; Nakagama, H.; Dashwood, R.H. Bcl-2 overexpression in PhIP-induced colon tumors: Cloning of the rat $\mathrm{Bcl}-2$ promoter and characterization of a pathway involving $\beta$-catenin, c-Myc and E2F1. Oncogene 2007, 26, 6194-6202. [CrossRef] [PubMed]

148. Zhang, G.; Ge, M.; Han, Z.; Wang, S.; Yin, J.; Peng, L.; Xu, F.; Zhang, Q.; Dai, Z.; Xie, L.; et al. Wnt/ $\beta$-catenin signaling pathway contributes to isoflurane postconditioning against cerebral ischemia-reperfusion injury and is possibly related to the transforming growth factor $\beta 1 / \mathrm{Smad} 3$ signaling pathway. Biomed. Pharmacother. 2019, 110, 420-430. [CrossRef]

149. Seifert-Held, T.; Pekar, T.; Gattringer, T.; Simmet, N.E.; Scharnagl, H.; Stojakovic, T.; Fazekas, F.; Storch, M.K. Circulating Dickkopf-1 in acute ischemic stroke and clinically stable cerebrovascular disease. Atherosclerosis 2011, 218, 233-237. [CrossRef]

150. Picard-Riera, N.; Nait-Oumesmar, B.; Baron-Van Evercooren, A. Endogenous adult neural stem cells: Limits and potential to repair the injured central nervous system. J. Neurosci. Res. 2004, 76, 223-231. [CrossRef]

151. Piccin, D.; Morshead, C.M. Wnt signaling regulates symmetry of division of neural stem cells in the adult brain and in response to injury. Stem Cells 2011, 29, 528-538. [CrossRef]

152. Wei, Z.Z.; Zhang, J.Y.; Taylor, T.M.; Gu, X.; Zhao, Y.; Wei, L. Neuroprotective and regenerative roles of intranasal Wnt-3a administration after focal ischemic stroke in mice. J. Cereb. Blood Flow Metab. 2018, 38, 404-421. [CrossRef] [PubMed]

153. Shruster, A.; Ben-Zur, T.; Melamed, E.; Offen, D. Wnt signaling enhances neurogenesis and improves neurological function after focal ischemic injury. PLoS ONE 2012, 7, e40843. [CrossRef] [PubMed]

154. Lei, Z.N.; Zhang, L.M.; Sun, F.Y. $\beta$-Catenin siRNA inhibits ischemia-induced striatal neurogenesis in adult rat brain following a transient middle cerebral artery occlusion. Neurosci. Lett. 2008, 435, 108-112. [CrossRef]

155. Lei, Z.-N.; Liu, F.; Zhang, L.-M.; Huang, Y.-L.; Sun, F.-Y. Bcl-2 increases stroke-induced striatal neurogenesis in adult brains by inhibiting BMP-4 function via activation of $\beta$-catenin signaling. Neurochem. Int. 2012, 61, 34-42. [CrossRef] [PubMed]

156. Zhao, Y.; Wei, Z.Z.; Zhang, J.Y.; Zhang, Y.; Won, S.; Sun, J.; Yu, S.P.; Li, J.; Wei, L. GSK-3ß inhibition induced neuroprotection, regeneration, and functional recovery after intracerebral hemorrhagic stroke. Cell Transplant. 2017, 26, 395-407. [CrossRef]

157. Wang, L.H.; Zhang, G.L.; Liu, X.Y.; Peng, A.; Ren, H.Y.; Huang, S.H.; Liu, T.; Wang, X.J. CELSR1 promotes neuroprotection in cerebral ischemic injury mainly through the Wnt/PKC signaling pathway. Int. J. Mol. Sci. 2020, 21, 1267. [CrossRef] [PubMed]

158. Yu, Z.; Cheng, C.; Liu, Y.; Liu, N.; Lo, E.H.; Wang, X. Neuroglobin promotes neurogenesis through Wnt signaling pathway. Cell Death Dis. 2018, 9, 945. [CrossRef]

159. Qi, C.; Zhang, J.; Chen, X.; Wan, J.; Wang, J.; Zhang, P.; Liu, Y. Hypoxia stimulates neural stem cell proliferation by increasing HIF- $1 \alpha$ expression and activating Wnt/ $\beta$-catenin signaling. Cell. Mol. Biol. (Noisy-le-grand) 2017, 63, 12-19. [CrossRef]

160. Chen, X.; Zhou, B.; Yan, T.; Wu, H.; Feng, J.; Chen, H.; Gao, C.; Peng, T.; Yang, D.; Shen, J. Peroxynitrite enhances self-renewal, proliferation and neuronal differentiation of neural stem/progenitor cells through activating HIF- $1 \alpha$ and Wnt/ $\beta$-catenin signaling pathway. Free Radic. Biol. Med. 2018, 117, 158-167. [CrossRef]

161. Wang, J.; Chen, T.; Shan, G. MiR-148b regulates proliferation and differentiation of neural stem cells via Wnt/ $\beta$-catenin signaling in rat ischemic stroke model. Front. Cell. Neurosci. 2017, 11, 329. [CrossRef]

162. Qiu, C.W.; Liu, Z.Y.; Hou, K.; Liu, S.Y.; Hu, Y.X.; Zhang, L.; Zhang, F.L.; Lv, K.Y.; Kang, Q.; Hu, W.Y.; et al. Wip1 knockout inhibits neurogenesis by affecting the Wnt/ $\beta$-catenin signaling pathway in focal cerebral ischemia in mice. Exp. Neurol. 2018, 309, 44-53. [CrossRef] [PubMed] 
163. Yu, G.; Liang, Y.; Zheng, S.; Zhang, H. Inhibition of myeloperoxidase by N-Acetyl lysyltyrosylcysteine amide reduces oxidative stress-mediated inflammation, neuronal damage, and neural stem cell injury in a murine model of stroke. J. Pharmacol. Exp. Ther. 2018, 364, 311-322. [CrossRef] [PubMed]

164. You, D.; You, H. Repression of long non-coding RNA MEG3 restores nerve growth and alleviates neurological impairment after cerebral ischemia-reperfusion injury in a rat model. Biomed. Pharmacother. 2019, 111, 1447-1457. [CrossRef] [PubMed]

165. Lee, S.H.; Ko, H.M.; Kwon, K.J.; Lee, J.; Han, S.-H.; Han, D.W.; Cheong, J.H.; Ryu, J.H.; Shin, C.Y. tPA regulates neurite outgrowth by phosphorylation of LRP5/6 in neural progenitor cells. Mol. Neurobiol. 2014, 49, 199-215. [CrossRef] [PubMed]

166. Morris, D.C.; Zhang, Z.G.; Wang, Y.; Zhang, R.L.; Gregg, S.; Liu, X.S.; Chopp, M. Wnt expression in the adult rat subventricular zone after stroke. Neurosci. Lett. 2007, 418, 170-174. [CrossRef]

167. Yang, J.; Zhang, X.; Wu, Y.; Zhao, B.; Liu, X.; Pan, Y.; Liu, Y.; Ding, Y.; Qiu, M.; Wang, Y.Z.; et al. $\mathrm{Wnt} / \beta$-catenin signaling mediates the seizure-facilitating effect of postischemic reactive astrocytes after pentylenetetrazole-kindling. Glia 2016, 64, 1083-1091. [CrossRef]

168. Busceti, C.L.; Di Menna, L.; Bianchi, F.; Mastroiacovo, F.; Di Pietro, P.; Traficante, A.; Bozza, G.; Niehrs, C.; Battaglia, G.; Bruno, V.; et al. Dickkopf-3 causes neuroprotection by inducing vascular endothelial growth factor. Front. Cell. Neurosci. 2018, 12. [CrossRef]

169. Zhang, D.; Lu, Z.; Man, J.; Cui, K.; Fu, X.; Yu, L.; Gao, Y.; Liao, L.; Xiao, Q.; Guo, R.; et al. Wnt-3a alleviates neuroinflammation after ischemic stroke by modulating the responses of microglia/macrophages and astrocytes. Int. Immunopharmacol. 2019, 75. [CrossRef]

170. Shang, Y.C.; Chong, Z.Z.; Hou, J.; Maiese, K. Wnt1, FoxO3a, and NF-кB oversee microglial integrity and activation during oxidant stress. Cell. Signal. 2010, 22, 1317-1329. [CrossRef]

171. Song, D.; Zhang, X.; Chen, J.; Liu, X.; Xue, J.; Zhang, L.; Lan, X. Wnt canonical pathway activator TWS119 drives microglial anti-inflammatory activation and facilitates neurological recovery following experimental stroke. J. Neuroinflammation 2019, 16. [CrossRef]

172. Halleskog, C.; Dijksterhuis, J.P.; Kilander, M.B.C.; Becerril-Ortega, J.; Villaescusa, J.C.; Lindgren, E.; Arenas, E.; Schulte, G. Heterotrimeric G protein-dependent WNT-5A signaling to ERK1/2 mediates distinct aspects of microglia proinflammatory transformation. J. Neuroinflammation 2012, 9. [CrossRef] [PubMed]

173. Cheng, J.; Shen, W.; Jin, L.; Pan, J.; Zhou, Y.; Pan, G.; Xie, Q.; Hu, Q.; Wu, S.; Zhang, H.; et al. Treadmill exercise promotes neurogenesis and myelin repair via upregulating $\mathrm{Wnt} / \beta$-catenin signaling pathways in the juvenile brain following focal cerebral ischemia/reperfusion. Int. J. Mol. Med. 2020, 45, 1447-1463. [CrossRef] [PubMed]

174. Nicaise, A.M.; Johnson, K.M.; Willis, C.M.; Guzzo, R.M.; Crocker, S.J. TIMP-1 promotes oligodendrocyte differentiation through receptor-mediated signaling. Mol. Neurobiol. 2019, 56, 3380-3392. [CrossRef] [PubMed]

175. Wang, L.; Geng, J.; Qu, M.; Yuan, F.; Wang, Y.; Pan, J.; Li, Y.; Ma, Y.; Zhou, P.; Zhang, Z.; et al. Oligodendrocyte precursor cells transplantation protects blood-brain barrier in a mouse model of brain ischemia via Wnt/ $\beta$-catenin signaling. Cell Death Dis. 2020, 11, 9. [CrossRef] [PubMed]

176. ClinicalTrials.gov. Available online: https://clinicaltrials.gov/ (accessed on 26 June 2020).

177. Marei, H.E.; Hasan, A.; Rizzi, R.; Althani, A.; Afifi, N.; Cenciarelli, C.; Caceci, T.; Shuaib, A. Potential of stem cell-based therapy for ischemic stroke. Front. Neurol. 2018, 9. [CrossRef] [PubMed]

178. Giuliani, D.; Ottani, A.; Neri, L.; Zaffe, D.; Grieco, P.; Jochem, J.; Cavallini, G.M.; Catania, A.; Guarini, S. Multiple beneficial effects of melanocortin MC4 receptor agonists in experimental neurodegenerative disorders: Therapeutic perspectives. Prog. Neurobiol. 2017, 148, 40-56. [CrossRef]

179. Spaccapelo, L.; Galantucci, M.; Neri, L.; Contri, M.; Pizzala, R.; D’Amico, R.; Ottani, A.; Sandrini, M.; Zaffe, D.; Giuliani, D.; et al. Up-regulation of the canonical Wnt-3A and Sonic hedgehog signaling underlies melanocortin-induced neurogenesis after cerebral ischemia. Eur. J. Pharmacol. 2013, 707, 78-86. [CrossRef]

180. Xing, Y.; Zhang, X.; Zhao, K.; Cui, L.; Wang, L.; Dong, L.; Li, Y.; Liu, Z.; Wang, C.; Zhang, X.; et al. Beneficial effects of sulindac in focal cerebral ischemia: A positive role in Wnt/ $\beta$-catenin pathway. Brain Res. 2012, 1482, 71-80. [CrossRef]

181. He, W.; Tian, X.; Lv, M.; Wang, H. Liraglutide protects neurite outgrowth of cortical neurons under oxidative stress though activating the Wnt pathway. J. Stroke Cerebrovasc. Dis. 2018, 27, 2696-2702. [CrossRef] 
182. Hu, Q.; Liang, X.; Chen, D.; Chen, Y.; Doycheva, D.; Tang, J.; Tang, J.; Zhang, J.H. Delayed hyperbaric oxygen therapy promotes neurogenesis through reactive oxygen species/hypoxia-inducible factor- $1 \alpha / \beta$-catenin pathway in middle cerebral artery occlusion rats. Stroke 2014, 45, 1807-1814. [CrossRef]

183. Chen, C.; Yang, Y.; Yao, Y. HBO promotes the differentiation of neural stem cells via interactions between the Wnt3/ $\beta$-catenin and BMP2 signaling pathways. Cell Transplant. 2019, 28, 1686-1699. [CrossRef] [PubMed]

184. Wu, C.; Chen, J.; Chen, C.; Wang, W.; Wen, L.; Gao, K.; Chen, X.; Xiong, S.; Zhao, H.; Li, S. Wnt/ $\beta$-catenin coupled with HIF-1 $\alpha$ /VEGF signaling pathways involved in galangin neurovascular unit protection from focal cerebral ischemia. Sci. Rep. 2015, 5, 16151. [CrossRef] [PubMed]

185. Qiu, C.W.; Liu, Z.Y.; Zhang, F.L.; Zhang, L.; Li, F.; Liu, S.Y.; He, J.Y.; Xiao, Z.C. Post-stroke gastrodin treatment ameliorates ischemic injury and increases neurogenesis and restores the Wnt/ $\beta$-Catenin signaling in focal cerebral ischemia in mice. Brain Res. 2019, 1712, 7-15. [CrossRef]

186. Xu, Y.; Zhang, G.; Kang, Z.; Xu, Y.; Jiang, W.; Zhang, S. Cornin increases angiogenesis and improves functional recovery after stroke via the Ang1/Tie2 axis and the Wnt/ $\beta$-catenin pathway. Arch. Pharm. Res. 2016, 39, 133-142. [CrossRef]

187. Chen, B.; Tao, J.; Lin, Y.; Lin, R.; Liu, W.; Chen, L. Electro-acupuncture exerts beneficial effects against cerebral ischemia and promotes the proliferation of neural progenitor cells in the cortical peri-infarct area through the Wnt/ $\beta$-catenin signaling pathway. Int. J. Mol. Med. 2015, 36, 1215-1222. [CrossRef]

188. Lambert, C.; Cisternas, P.; Inestrosa, N.C. Role of Wnt signaling in central nervous system injury. Mol. Neurobiol. 2016, 53, 2297-2311. [CrossRef]

189. Scott, E.L.; Brann, D.W. Estrogen regulation of Dkk1 and Wnt/ $\beta$-Catenin signaling in neurodegenerative disease. Brain Res. 2013, 1514, 63-74. [CrossRef]

190. Wang, W.; Li, M.; Wang, Y.; Li, Q.; Deng, G.; Wan, J.; Yang, Q.; Chen, Q.; Wang, J. GSK-3ß inhibitor TWS119 attenuates rtPA-induced hemorrhagic transformation and activates the $\mathrm{Wnt} / \beta$-catenin signaling pathway after acute ischemic stroke in rats. Mol. Neurobiol. 2016, 53, 7028-7036. [CrossRef]

191. Libro, R.; Bramanti, P.; Mazzon, E. The role of the Wnt canonical signaling in neurodegenerative diseases. Life Sci. 2016, 158, 78-88. [CrossRef]

192. Tran, F.H.; Zheng, J.J. Modulating the wnt signaling pathway with small molecules. Protein Sci. 2017, 26, 650-661. [CrossRef] [PubMed]

193. Zhan, T.; Rindtorff, N.; Boutros, M. Wnt signaling in cancer. Oncogene 2017, 36, 1461-1473. [CrossRef] [PubMed]

(C) 2020 by the authors. Licensee MDPI, Basel, Switzerland. This article is an open access article distributed under the terms and conditions of the Creative Commons Attribution (CC BY) license (http://creativecommons.org/licenses/by/4.0/). 